\title{
Discrimination in the Credit and Housing Markets: Findings and Challenges
}

\author{
Gary A. Dymski*
}

October 17, 2002; Revised, April 13, 2005

Economics all too seldom provides straightforward guidelines for designing and analyzing statistical materials on subjects of great social importance. Since the economic theory of discrimination does provide a simple approach, it is too bad that studies of whether banks discriminate in mortgage lending have not utilized these insights.

- Gary Becker (1993, P. 18)

Eventually, even the definition of discrimination comes to mean different things to blacks and whites.

-- Derrick Bell (1980, P. 658)

\section{Introduction}

This essay summarizes the main lines of research on discrimination in the housing and credit markets, and develops an explanation for the prevalence of the ongoing controversies among analysts of these phenomena. There are sizeable literatures on racial discrimination in the credit and housing markets. ${ }^{1}$ However, this does not mean that academic researchers have agreed on a core set of findings and come to many definite conclusions. To the contrary, findings are contentious, and conclusions challenged. Studies often beget counterstudies. Taken as a whole, academic debate has reached no definitive conclusions about whether applicant race and gender and neighborhood racial composition per se affect housing and credit market outcomes. Residents of minority communities might regard this uncertainty as surprising, if not socially irresponsible. But this $i s$ the situation: premises that are common wisdom in lived communities are debated fiercely and inconclusively in think tanks and universities.

Consequently, this assessment must also investigate the persistence of academic controversy. This chapter attributes the inconclusiveness of the academic literature to several factors: the ambiguity of legal and theoretical definitions of discrimination; the inescapability of the point of view of the observer and observed in empirical studies of racial discrimination; and the way in which empirical methodologies require research questions to be framed. To achieve precise empirical results, academic researchers have focused on narrow portions of a broad conceptual and historical terrain. Only when this tension between the narrower terrain of empirical work and the broader terrain of the social dimensions of discrimination is acknowledged can analysts who have been talking past one another find ways to communicate.

\footnotetext{
*Director, University of California Center Sacramento. Email: gary.dymski@ucop.edu. Forthcoming in the Handbook on Discrimination (Edward Elgar), edited by William Rodgers. ${ }^{1}$ Literature reviews on credit and housing market discrimination include Turner, Fix, and Struyk (1991), Cloud and Galster (1993), Dymski (1997), Ladd (1998), and Austin Turner and Skidmore (1999a). Schmitt's original synthesis (2000) emphasizes credit-scoring.
} 
This chapter touches almost exclusively on racial discrimination, with limited attention to gender discrimination and virtually none to sexual-preference or other forms of discrimination. In addition, discussion centers on discrimination involving African Americans and Latinos. ${ }^{2}$

We proceed as follows. Section 2 describes the legal context of the economics of creditmarket and housing-market discrimination. Section 3 sets out the theoretical behavioral models that have guided most empirical work in this area. Section 4 reviews empirical studies of racial redlining and racial discrimination in the credit market. Section 5 considers the impact of the financial evolution on discrimination, with special attention to predatory lending. Section 6 then discusses empirical work on racial discrimination in housing markets. Section 7 considers work on gender discrimination in these two markets. Section 8 then explores the significance of cultural affinity, networks, and wealth. Section 9 concludes.

\section{The Legal Context of Discrimination in Credit and Housing Markets}

The roots of the controversy over measuring racial discrimination in the credit and housing markets lie in the independent origins of empirical and theoretical work on these intertwined topics. Empirical work on housing and credit-market discrimination has its origins in Congressional action against racial and other forms of discrimination in the 1960s and 1970s. Theoretical models of discrimination evolved with virtually no reference to Civil Rights-era legislation. The core models in this area of investigation suggest that racial discrimination may either be benign - in the sense that those who practice racial exclusion bear all costs of their discriminatory actions - or rational. So while the legal view of discrimination in these markets is prepared to find and punish perpetrators, theoretical models are predisposed to the conclusion that action against the racially-biased is either unnecessary or inefficient. ${ }^{3}$

This section sets out the legal context. We begin with a definition. ${ }^{4}$ At any point in time,

\footnotetext{
2 The terms 'black' and 'brown', respectively, are sometimes used to refer to these two racial/ethnic categories. The term 'Latino' only imperfectly captures the set of all individuals whose cultural and residential roots are in former colonies of Spain and Portugal; the term 'Hispanic,' which is not used here, is perhaps more problematic. Since the term 'Hispanic' is often used in empirical investigations, this implies that the problematic classification of this population is built into many of the studies discussed here. There is virtually no attention herein to the credit-market and housing discrimination problems faced by Asian Americans, Pacific Islanders, and Native Americans; this reflects the orientation of the studies reviewed here. Dymski (1999) does discuss these populations' experience with home-mortgage discrimination. His study - which encompasses 18 states and 120 metropolitan areas -- incorporates areas where these populations' share of the borrower base permits meaningful empirical results.

${ }^{3}$ Freeman (1978) first used the term "perpetrators" in this context. In the "perpetrator" perspective: all racial inequalities stem from biased perpetrators; so if perpetrators are deterred, discrimination will disappear.

${ }^{4}$ An apology is also in order. There is a large, robust, and adventurous legal literature on the topics of housing and credit-market discrimination. It is largely ignored here; the economicsbased literature absorbs our attention. Those interested in legal perspectives on credit-market
} 
discrimination occurs whenever agents who individually share some common characteristic can complete a market transaction only at a higher cost or more stringent terms than other agents; it also occurs when agents sharing this characteristic are less likely to succeed in an uncertain market transaction (such as applying for a loan), or have less access to resources. This discrimination can be based on one or more characteristics of agents-race, sexual preference, gender, age, national origin, and so on. Implicitly, the social (and legal) concern over prevalent discrimination arises insofar as it is consequential - that is, if it affects agents' relative wellbeing through time. John Roemer (1998) has recently suggested that equality of opportunity is compromised when two sets of agents have differential opportunities for success and achievement (and, we might add, for consumption) due to an ascriptive difference. Inequality of opportunity serves as a useful criterion for establishing whether discrimination is consequential.

Race is a protected category under the U.S. Constitution's "equal protection" doctrine; the $14^{\text {th }}$ Amendment to the Constitution, passed in 1868 in response to various states' "black codes," established that no state "shall make or enforce any law which shall abridge the privileges or immunities of the citizens of the United States ... [or] deprive any person of life, liberty, or property without due process of law, [or] deny to any person within its jurisdiction the equal protection of the laws." Congress passed several statutes to implement this Amendment, including the Civil Rights Act of 1866, which guarantees the right "to make and enforce contracts" (42 U.S.C. $§ 1981)$. However, over the years the Supreme Court restricted the applicability of the $14^{\text {th }}$ Amendment to the action of states.

Federal housing policies to encourage home-ownership, until the 1970s, embodied overt racial bias against minorities and minority areas. ${ }^{5}$ The rise of the Civil Rights movement in the 1950s created social pressure for change, especially with respect to racial injustice as it affected African Americans. In November 1962, Executive Order 11063 banned discrimination in all federally assisted housing. Congress then used its powers to regulate interstate commerce to pass the Civil Rights Act of 1964, which extended the $14^{\text {th }}$ Amendment to the actions of individuals, universities, and other entities. Subsequent statutes brought various substantive areas explicitly under the scope of this Act. The Fair Housing Act of 1968 makes it "unlawful for any person or other entity whose business includes engaging in residential real estate-related transactions to discriminate against any person in making available such a transaction, or in the terms or conditions of such a transaction" (42 U.S.C. $\$ 3601$ et seq.). ${ }^{6}$ This Act identifies seven classes protected by the law: race, color, national origin, religion, sex, familial status and disability. Similarly, the Equal Credit Opportunity Act (ECOA) of 1974 makes discrimination against loan applicants unlawful.

discrimination might begin with Schwemm (1995) and Swire (1995); those interested in housing discrimination, with Calmore (1998) and Wiggins (2002).

${ }^{5}$ See Squires (1992); this author also provides an overview of the US community reinvestment movement. Stuart (2003) provides a remarkably thorough institutional analysis of the historical development of the home-mortgage industry in the U.S., with special attention to the problem of racial discrimination.

${ }^{6}$ Dubovsky (1969) provides a blow-by-blow legislative history of the passage of the Fair Housing Act of 1968. 
Numerous court cases and Congressional fine-tuning have clarified the legal meaning of discrimination and shaped federal policies. In March 1994, the federal agencies responsible for punishing credit-market discrimination issued a unified policy statement incorporating these clarifications. Three types of racial discrimination are identified (Marsden (1994)):

- overt discrimination-refusing to initiate a transaction with a person of color

- disparate treatment—screening minorities more harshly than whites in application processes, or subjecting minority applications to different application processes

- disparate impact - conducting commercial practices that disproportionately harm a racial minority without being justified by a legitimate business need.

The first two elements of this list emphasize discrimination as intentional behavior. Both suggest that racial or other forms of discrimination can be traced back to racial "perpetrators": in the first case, these perpetrators are engaging in willed and purposive behavior aimed at blocking minorities; in the second case, a behavioral can be identified which may not be intentional, but which has non-neutral effects. There is a smoking gun for diligent investigators to unearth.

The third element of the above list is different. It refers to situations in which procedures that are racially neutral on their face lead to ex-post racial disparities unrelated to economic fundamentals. In effect, if no legitimate business-related reason for making racial distinctions can be identified, then racial divisions in market outcomes are presumed to be socially illegitimate. They inhibit all citizens' ability to "make and enforce contracts." No distinction is made about whether these racial divisions result from actions intended to produce these effects.

Many types of loan and housing market could serve as vehicles for any of these types of discrimination. In the early 1970's, home-mortgage markets were brought to the fore in policy debates about discrimination in these markets, as a broad-based movement of community-based groups exposed the "redlining" of inner-city neighborhoods. Redlining involves a decision by either lenders or realty agents to avoid or make fewer transactions in a given area, due to its "riskiness." Community groups, sometimes working with intrepid social scientists, collected data showing that systematically fewer home loans or insurance policies were being recorded in some areas than others. ${ }^{7}$ The areas being redlined typically had higher minority populations than other areas - so this behavior could be linked to lenders' or brokers' spatial racial biases. Ironically, until the mid-1960s, the federal government's principal home-mortgage underwriting program (the FHA program), which accounted for nearly half of all homes sold in the 1950s and 1960s, itself used explicitly racial (and racist) criteria about neighborhoods in making decisions about whether to approve FHA loans. So redlining was not a phantasm of overzealous activists: it had been official government policy. The relation between racial discrimination and redlining was then as follows: the former disadvantages an agent independent of her location; the latter disadvantages agents in a location independent of their individual characteristics.

To clarify the extent of this problem, Congress passed the Home Mortgage Disclosure Act (HMDA) in 1975; this legislation required lenders to report the number and dollar volume of residential loans by census tract. The data collected under the HMDA, together with continued

\footnotetext{
${ }^{7}$ Early redlining studies are discussed Bradford et al. 1977, Part II. Redlining sometimes took the form of higher transaction costs or worse contractual terms and conditions.
} 
grassroots pressure, were sufficient to convince Congress to pass the Community Reinvestment Act of 1977 (CRA), which requires banks to meet credit needs in their entire market area. ${ }^{8}$ This affirmative obligation to meet credit needs evenly was interpreted by community-based groups as a mandate to end redlining.

The existence of HMDA and the CRA mandate generated considerable controversy in localities throughout the nation. Local groups alleged bias; bankers and brokers responded that the allegedly redlined areas also had worse economic fundamentals than other areas, as well as a systematically lower demand for credit and home ownership. If the presence of racial bias as an important element in redlining (keeping in mind the legacy of the FHA program) could not be proven, its possibility could not be dismissed. When the thrift bail-out bill passed in 1989, activists and Congressmembers used the horse-trading possibilities this act afforded to require more detailed reporting under HMDA. As of 1990, banks and other mortgage lenders over a specific asset-size threshold have been required to report data on every mortgage loan application, including the applicant's race and income and the disposition of the application. These reporting requirements have been fine-tuned almost continuously since then; this finetuning takes the form of amendments to Regulation $\mathrm{C}$, which implements HMDA. Most of this fine-tuning has been incremental; but in 2002, changes to Regulation C required that as of January 1, 2004, institutions report information about the loan rate charged and also more detailed borrower race/ethnic information. ${ }^{9}$

\section{Theoretical Models of Discrimination and Redlining in Credit and Housing Markets}

The politically-charged rise of civil-rights legislation concerning processes and outcomes in housing and credit markets (among other markets) found little initial support in the realm of economic theory. The one existing text that explicitly examined the behavioral foundations of racial discrimination from a theoretical viewpoint was Becker's 1957 volume, which he expanded in a 1971 second edition. This model traces race effects in housing and labor markets to individual agents' racial bigotry. It presupposes that some whites so dislike minorities that they will pay a premium or accept lower wages or profits to avoid dealing with minorities in home or business settings. Becker goes on to argue that discriminators themselves bear the costs of discrimination, given free entry into these markets. So discrimination will die a natural death as discriminators tire of its price; no policy intervention is needed to overcome it, just free entry into markets. This theory, in short, links discrimination to perpetrators, and perpetrators' behavior to racial preferences; and it concludes that little or no interference in the market is needed to address this evidently "social" problem.

This story is deceptively simple: its conclusion follows only given a particular

\footnotetext{
${ }^{8}$ The language of the act states that lenders "have a continuing and affirmative obligation to help meet the credit needs of the local communities in which they are chartered" (para. 802(a)(3), 12 USC 1901; Title VII of Public Law 95-128, 91 Stat. 1147, Oct. 12, 1977). Fishbein (1992) discusses CRA's purposes and documents the evolution of HMDA reporting requirements. ${ }^{9}$ For information on HMDA regulations, see http://www.ffiec.gov/hmda/about.htm. The loanrate information to be collected is rate-spread data: specifically, the difference between the loan rate and the rate on Federal government securities of comparable maturity.
} 
specification of preferences and market structure. The effects of racial preferences depend on the relative numbers of minority and white agents, on how many are bigoted, on the freedom of market entry, and on whether market participants face transaction and/or information costs. ${ }^{10}$ Consider the housing market. If only some real-estate agents in a given area are bigoted, minority home-seekers should be able to turn to unbigoted agents for assistance, paying no penalty apart from shoe-leather costs. But if all real-estate agents are equally bigoted and entry into their business is costly, minorities may pay a premium for lower-quality homes. If white residents alone are bigoted, whites may pay a premium to live in areas with few minorities (Becker's case); but if racial covenants or other means of legal exclusion force all minority residents into restricted housing quarters, rents in minority areas will command a premium.

Several authors have extended Becker's model to the credit market. Dymski (1995) shows that racially-neutral bankers might offer stricter credit terms to borrowers in white than in minority communities if enough whites are bigoted; but if some minorities prefer white communities, "rational" (racially neutral) bankers might protect their profits by practicing personal discrimination against these prospective borrowers. Han $(2001,2004)$ develops a tastebased model more complete than Becker's in that it derives loan terms endogenously. He finds that whether loans to minority borrowers have higher expected profit rates (the mirror image of the 'perpetrator pays' view) depends crucially on how profitability is measured.

Some theoretical models of housing-market discrimination developed in the 1970's, which extend a Becker-type framework to the housing market, continue to inform contemporary audit tests. ${ }^{11}$ These models examine what happens when housing search is costly and white agents or residents may be racial bigots; see Masson (1973), Lee and Warren (1977), Courant (1978), and Cronin (1982). These models uniformly suggest that Becker's perpetrator-pays property does not hold in the housing market. In particular, white prejudice makes housing search costlier for minority home-seekers than for white home-seekers; thus minorities will search less, pay more, and be less satisfied, ceteris paribus. Yinger's model of the rental market (1975) shows that racially-neutral landlords with bigoted white residents might discriminate against minority tenants in choosing tenants_again, passing discrimination costs along to minorities. $^{12}$

${ }^{10}$ Arrow's (1971) general-equilibrium model of discrimination is much clearer than Becker's original model in exposing Becker's fundamental logic. Mason (1992) demonstrates that Becker's conclusions depend on his model's assumptions.

${ }^{11}$ An audit study of discrimination - also referred to as a paired-testing study - probes for the presence or absence of behavioral bias by comparing the real-time responses of agents involved in the home-buying and/or loan-making process to white and to minority home and/or loan seekers. The idea is to train pairs of testers who play the role of home and/or loan seekers; in their roles as testers, these 'applicants' have identical economic characteristics (income, wealth, housing demand, debt, and so on); they differ only in their racial/ethnic (or gender, or age, or any other binary characteristic). Then the treatment of 'applicants' with different profiles (racial/ethnic or other, as noted) is compared. This permits a direct behavioral 'audit' of the impact of the characteristic of interest on market outcomes. Audit studies of credit- and housingmarket behavior, respectively, are reviewed in sections 4 and 6 below.

${ }^{12}$ We also mention in this context Schelling's game-theoretic model of racial tipping (1971), which shows how static equilibria of the sort Becker theorizes can be dynamically unstable. 
Overall, these results suggest that when market entry isn't free, when minorities as well as whites have racial preferences, or when information costs exist, discrimination costs may not be borne by bigots, and hence racial differences may not lessen over time. These results all are motivated by situations in which one or another set of agents have preferences about dealing with certain classes of agents. Agents in these models are taken one-by-one. Richer outcomes can emerge, however, when agents' spatial locations are identified, and when agents in the same discriminatory category (such as race) live in concentrated areas. In this case, spillover effects among agents may emerge; and generalizations (for example, on the basis of the racial characteristics of an area) can be made. For example, Zenou and Boccard (2000) develop a model in which spatial mismatch exists (with jobs located disproportionately in the suburban fringe, not the urban core), in which black workers are subject to racial discrimination in the job market, and in which employers discriminate against urban-core workers. In this case, as the authors put it, "both race and space are responsible for the high unemployment rate among blacks" (p. 260); spatial spillovers amplify racial biases and generate cumulative segregation and unemployment impacts.

Informational problems can lead to racial redlining even when no agents are Becker-type bigots. Shifting attention to the credit market, Stiglitz and Weiss (1991) show that the asymmetric distribution of information about creditworthiness between banks and potential borrowers in white and minority communities can lead to redlining. If banks cannot distinguish good from bad individual borrowers, but know that projects in the minority community are riskier than those in the white community, they may redline the minority community to avoid excess exposure to risk. ${ }^{13}$

Why will loans in the minority community be riskier? Two theoretical explanations have been proposed. The first argument, originally suggested by Guttentag and Wachter (1981), and then refined by Lang and Nakamura (1993), explains redlining as due to neighborhood externalities and information costs. The argument goes that in any community, the return on (or variability of) lending depends on the total volume of lending there. Given this, lenders concentrate their lending where other lenders are making loans. The second argument, made by the same authors, asserts that if it is costly to gather information on individual borrowers, and if borrowers' race and economic fundamentals are correlated, lenders can "rationally" use neighborhood racial composition as a low-cost substitute for costly information-gathering. ${ }^{14}$

Neighborhood spillovers may also cause coordination failures among lenders: refurbishment effects, wherein home sales lead to refurbishment by their new owners, enhancing the value of all homes in the neighborhood; liquidity effects, wherein home sales enhance all

${ }^{13}$ Note that the authors set out this finding explain this practice (not to condemn it). That is, given that missing information makes first-best equilibria (the most qualified applicants are readily identified and provided with loans) impossible, and given that some methods of achieving second-best equilibria are more costly than others, the use of neighborhood race may emerge as the most cost-efficient method of identifying a borrower pool with less risk than a randomly-chosen pool.

${ }^{14}$ This last idea is an application of the "statistical" theory of discrimination, which Arrow (1971) and others developed to explain racial screening in the labor market. 
neighborhood homes' values by increasing these homes' liquidity; and branch spillover effects, wherein bank branches function as pure public goods in their local neighborhoods (Dymski (1995)). ${ }^{15}$ Further, intermarket linkages can also be pivotal in credit-market outcomes: given racial discrimination in the labor market (see Austin Turner, Fix, and Struyk (1991)), banks might "rationally" discriminate against minority loan applicants who are as qualified as whites, due to minority applicants' lower or more variable future earned-income levels. Discrimination could take the form of either disparate treatment of individual minority applicants or the redlining of minority neighborhoods. Feedback effects from the credit market to the markets for earned income, of course, are also possible, though these are not explored in this paper.

Summary. Theoretical models have suggested three roots of discriminatory market processes - that is, market outcomes that widen racial differences in access to or control of economic resources: ${ }^{16}$

(1) Personal discrimination (bigotry): racially differential outcomes that are due to racial preferences unrelated to economic factors.

(2) Rational discrimination: racially differential outcomes which arise when agents use race or characteristics correlated with race to make valid statistical inferences about the distinct market prospects of different racial groups.

(3) Structural discrimination: racially differential outcomes that arise because of identifiable economic factors associated with the agents or property involved.

Category (2) refers to outcomes based on anticipated disparities, and category (3) to those based on existing disparities. An example may clarify the difference. Suppose whites and minorities are members of a loan pool for a limited number of loans; and suppose credit will be allocated on the basis of their current levels of wealth and their prospective levels of earned income. Minorities are subject to structural discrimination if they have lower average wealth levels than whites and are chosen less often for loans on this basis; if minority and white wealth levels are the same, minorities are subject to rational discrimination if loans are based on prospective income and minorities' average prospective incomes are lower than whites.

Ideally, the theoretical framework that underlies any given literature should provide unambiguous basic behavioral categories that can be used to anchor applied analyses. This framework, however, does not generate clear and unambiguous linkages between motivations and outcomes, or between market processes and legal prohibitions against discrimination. Becker's model attempted to tell a simple and reassuring story - that racist agents in markets were not only economically irrational, but also self-liquidating. However, subsequent work on his framework has shown that even the meaning of discrimination becomes very murky in the presence of intermarket linkages, complex patterns of preference, or search costs. Racial perpetrators may not pay the costs of their discrimination; so Becker's conclusion that discrimination is unsustainable seems unwarranted. Worse, Han (2001) shows that if taste-based discrimination exists, then outcomes that might be regarded as evidence of statistical

15 The term "coordination failure" refers to any occasion on which market processes fail to achieve outcomes that yield the highest achievable level of social welfare.

${ }^{16}$ While the literature reviewed here has implications for all forms of discrimination in credit and housing markets, it has focused almost exclusively on race. 
discrimination (such as stricter terms and conditions, higher denial rates, and so on) may instead result from taste-based discrimination. Under at least some circumstances, then, taste-based and statistical discrimination may be observationally equivalent. ${ }^{17}$

Subsequent theoretical models, based on lender/borrower asymmetric information, showed that these phenomena can arise even without non-neutral racial preferences. "Rational" discrimination can arise for several reasons, taking the form of either discrimination against individuals or redlining. So there can be racial bias without racial intent - there can be, so to speak, "benign" racial perpetrators, motivated not by blind hatred but by profit. Indeed, Scalera and Zazzaro (2001) show that with incomplete information, statistical discrimination based on misinformation or other prejudices about membes of a group can generate worsened performance over time, justifying the initial perceived group effect.

Do these conceptual ideas about discrimination provide justifications for legal action against it? The mapping from the three categories of discriminatory market process to the three types of prohibited behavior is not exact. For certain, personal discrimination based on bigotry is identical with overt discrimination. And while the "market" may in some cases "punish" personal discriminators, as Becker envisioned, in other cases the discriminatees will pay the cost - justifying the existence of legal remedies on the basis of discrimination.

The last two items in the above list have a more uncertain link to civil-rights law. Clearly, rational discrimination can both justify disparate treatment and generate disparate impact. This can be due to screening processes either at the level of individual applicants in a given market, or at the level of residents of a given neighborhood - that is, either discrimination or redlining can be "justified" on the basis of cost. This sets up at least a trade-off between profitability and equal protection against unfair discrimination. The key question then becomes, what is the required level of effort by those controlling resource flows in the credit and housing markets? Suppose the standard is that equal protection considerations are relevant only if they do not impose any costs; then the disparate treatment and disparate impact criteria will apply only if evidence of bigotry in the application of these criteria is also found. But this reduces to the first legal criterion, against overt discrimination. Similarly, structural discrimination, insofar as it reflects the historical legacy of earlier market outcomes, can be the basis of a legal disparate-impact claim only if overt discrimination can be identified in the markets in question.

Economists who have addressed the legality of rational discrimination -- Guttentag and Wachter (1981) and Calomiris et al. (1994) - have argued for it. This reflects a judgement that lenders' (brokers') required level of effort in the profitability/equal protection tradeoff should be zero - that economic efficiency should absolutely dominate any other social criterion. But, in a contest between due process and economic rationality, should it be protection against disparate treatment that gives way? This is inescapably a political question, not just an economic one.

\section{Empirical Studies of Redlining and Discrimination in the Credit Market}

Section 3 has shown that economic theories of discrimination have been developed

${ }^{17}$ Arrow (1998) makes the same point in a more general discussion of racial discrimination. 
independently of the legal benchmarks set out in section 2, with the result that the fit between theory and legal framework is inexact. Tensions exist about what constitutes discriminatory behavior, and consequently about what behaviors are illegal under civil rights law and what behaviors are unresponsive to the broader aims of housing and credit-market policy. Similarly, the theoretical models describing housing and credit-market discrimination use diverse methods and assumption sets. It is hardly surprising, then, that a wide range of empirical models have been used to depict discriminatory outcomes in housing and credit markets; nor is it surprising that the value of these empirical results has been a topic of ongoing debate and controversy.

Data limitations have precluded the statistical study of racial inequality and discrimination in most credit markets. On occasion, researchers have been able to exploit datasets encompassing particular markets and historical periods. For example, Olney (1998) shows how racial discrimination by lenders and racial differences in household collateral interacted in complex ways in the markets for merchant and installment credit in the interwar period. Olney's results suggest substantial discrimination in merchant credit markets, leading to racially differential liquidity constraints. ${ }^{18}$ Martin and Hill (2000), in turn, find evidence consistent with the presence of statistical racial discrimination in the auto-credit market; however, in contrast to Olney, they suggest that this discrimination may be 'rational' for lenders.

The exception to this rule is the case of housing-credit markets. As noted in section 2, Congress passed into law in 1975 an act requiring lenders to report annual data on homemortgage flows. This has focused researchers' attention on redlining and/or racial discrimination in home-mortgage markets. In effect, this fedeal legislation, as amended over time, has both provided data for innumerable studies, and has called forth studies of home-mortgage markets using other data and other approaches. Austin Turner and Skidmore (1999b) provide an excellent introduction to this vast body of work. They view discrimination in the context of a loanapproval process they divide into four stages: advertising and outreach; pre-application inquiries; loan approval/denial and/or terms and conditions; and loan administration. Their volume reports on studies and industry trends involving each step of this process, documenting that the pattern and practice of discrimination involves inter-linked multi-phase processes. Some trends that appear on the surface to be independent of racial discrimination are not: for example, these authors show that bank branch closures in minority neighborhoods have a discriminatory effect.

The next two subsections provide a more detailed summary of empirical studies of racial redlining and discrimination in the credit and housing markets that have relied on homemortgage-loan data. The discussion then turns to audit studies of credit market behavior, studies of small-business credit markets, and finally, studies of subprime and predatory credit markets. ${ }^{19}$

\footnotetext{
${ }^{18}$ Two recent papers - Hawley and Fujii (1990) and Crook (1999) -- use responses from the 1983 and 1995 Surveys of Consumer Finance to demonstrate in both cases that minority households are more likely than whites to refrain from applying for credit because they think they will be turned down, ceteris paribus. The implication of this finding for econometric studies of discrimination are noted below.

${ }^{19}$ Implicitly, most advocacy regarding home-mortgage credit, and most studies, have centered attention on the access of inner-city and minority neighborhoods and households to "mainstream" markets (that is, markets serving customers with standard levels of income and
} 
The redlining model. For years, community activists have argued that banks have violated the CRA and ECOA and contributed to inner-city decline by leaving good credit risks there unfunded. Banks' defenders have responded that banks cannot afford uneconomic loans in the competitive post-deregulation era; and anyway, the market abhors a vaccuum-so non-bank lenders attuned to neglected neighborhoods will keep financial markets efficient by meeting any financial needs banks no longer serve.

HMDA data have served both sides in this debate, which has had two phases, corresponding to the two levels of bank reporting since HMDA became law in 1975. Initially, community-based organizations would simply amass counts of loans and dollar flows in different subareas of U.S. cities. Once academic researchers were engaged, they could use HMDA data to construct redlining models of the form:

\section{Detrended mortgage flows in a given area $=f($ Area economic variables, Area social variables [including area race])

Prior to 1990, lenders covered by HMDA reported annually only on the number and dollar value of mortgages made by census tract; so dependent (left-hand-side) variables could be no more specific than that shown in equation (1). The logic of equation (1) is this: area economic variables might legitimately affect housing value, and hence mortgage flows; but if mortgage decisions are based solely on economic fundamentals, then area social variables, including neighborhood racial composition, should be insignificant. Redlining arises when area race affects loan flows, even after controlling for economic fundamentals. ${ }^{20}$

Three approaches have been used to establish redlining. One approach is to estimate equation (1) by census tract; redlining is inferred if loan flows fall as minority population increases. The first published studies of redlining using HMDA data (Ahlbrandt (1977), Hutchinson et al. (1977), and Schafer (1978)) took this approach. This is a flawed test if redlining occurs by neighborhood: census tracts are too small to qualify as distinct "neighborhoods," and larger communities are ignored. ${ }^{21}$

earnings risk). This is not to ignore non-standard markets and practices, which historically have been located in minority areas for more frequently than in non-minority neighborhoods. For example, Caplovitz (1967) documents the existence of many exculpatory financial practices in the 1960s; Barr (2004) and Caskey (1994) document the omnipresence of such practices, dubbed "fringe banking," in the current period. Insofar as race, income, and wealth levels are correlated, minorities are more likely to be victimized by such arrangements - or, to view things differently, to be recurrent "cash and carry" in fringe banking arrangements.

${ }^{20}$ Mortgage flows must be detrended to remove scale effects. This is normally done by dividing raw loan flows by the single-family housing stock in each census tract. The logarithms of loan flows can be used if the list of regressors includes single-family structures.

${ }^{21}$ LaCour-Little and Green (1998) published a variant of this census-tract-based approach. Using the 1990 Boston data set (discussed in the next subsection of this chapter), they found that highminority areas were likely to have systematically lower appraisals, a factor that would lead to lower mortgage flows, ceteris paribus. Offsetting this indirect evidence of redlining by race was 
A second approach corrects this problem by separating data into geographic subsets corresponding to community boundaries. Bradbury, Case, and Dunham (1989) grouped Boston's census tracts into 60 "neighborhoods"; Shlay (1989) divided Chicago into suburban, gentrified, and "neighborhood" areas. These studies (and others) have found that loan flows vary negatively with minority population, so minority and inner-city neighborhoods are not receiving what Shlay terms their "fair share" of mortgage credit. This approach is subject to pre-selection bias. ${ }^{22}$

A third approach to redlining remedies the pre-selection bias problem by using a neutral method for sorting census tracts. The well-known Atlanta study (Dedman (1988)) divided tracts into five tiers based on median income, and three distinct tiers based on minority population. A subsequent study of Los Angeles (Dymski and Veitch (1994)) divided that city's census tracts into quintiles based on median income and on minority population. Both studies evaluated the sensitivity of loan flows to racial composition for each income tier separately. Both studies found dramatically lower loan flows in high-minority tracts. ${ }^{23}$ This third method has the same flaw as the first: its tier groupings map spatially contiguous communities only imperfectly.

Numerous criticisms of all these models of redlining have been made. These studies do not control for whether lower loan flows in minority areas are due to lower loan demand there (Benston (1981)). Further, areas that are apparently redlined may have greater lending risks (Holms and Horvitz (1994)), due to greater residential turnover and a higher proportion of renters (Canner (1981)) or to market failure (Guttentag and Wachter (1981)). ${ }^{24}$ In effect, skeptics have viewed redlining as a spurious statistical result, and argued that only more complete data could determine whether what appears to be bank redlining behavior is dictated by economic factors. As Canner puts it:

Far from being arbitrary or irrational lender behavior, redlining is the competitive market outcome of utility-maximizing households and profit-maximizing mortgage lenders.

the fact that neighborhood quality and racial composition were correlated across census tracts, suggesting that the apparent impact of "racial composition" on assessed-value levels might be due to "neighborhood quality" factors.

${ }^{22}$ Pre-selection bias arises because the suspicion that a certain geographic area is subject to redlining is not independent of the statistical test for whether it is. For example, a researcher could accuse a bank of unfairly treating neighborhood $\mathrm{X}$, on the basis of data concerning loanflow gaps in X. A variety of bank policies could generate gaps of the sort observed; finding X gaps is not sufficient to demonstrate the bank uses $\mathrm{X}$ as an operational variable in its decisionmaking process.

${ }^{23}$ Both studies also supplemented HMDA data with transactions data to examine the impact of the non-bank mortgage lenders, especially mortgage companies, not covered under HMDA. In both cases, non-bank lenders did not close the lending-disparity gaps left by HMDA-reporting lenders.

${ }^{24}$ Galster (1992) provides a comprehensive survey of studies that criticize the redlining model. Market failure occurs when markets fail to give the right resources to the right agents at the right prices due to one or more impediments. For example, market-failure redlining could occur if lenders fail to make loans in an area because they believe other lenders may avoid it too. 
Conventional mortgage redlining is only slightly different in form from the more traditional price rationing that characterizes all competitive free markets (Canner 1981: 68).

This argument shifts the burden of proof from the presumption that fair market outcomes should be racially neutral to the presumption that efficient market outcomes may be racially nonneutral. If evidence of racial and other forms of redlining cannot prove racial or other biases in lending markets, neither is it true that all evidence of racial redlining signifies nothing. Given the U.S.'s legacy of residential segregation and the vast disparities in market and non-market resources among urban neighborhoods (Massey and Denton (1993)), evidence of racial redlining constitutes at least a warning beacon, an indicator that credit flows are contributing to or subtracting from the balance sheet of American racial inequality. ${ }^{25}$

Mortgage discrimination models. Several studies in the 1970's and 1980's, including the Atlanta study cited above, obtained non-HMDA data about individual mortgage applicants and found stronger evidence of discrimination. And as of 1990, HMDA reporting requirements have required lenders to collect data on applicants. These data allow researchers to estimate reduced-form discrimination equations that incorporate more elements of demand and supply, of the form:

\section{Probability of loan denial for a given applicant pool $=f($ Individual economic variables, Individual social variables [including individual's race], Area economic variables, Area social variables [including area race])

The first study of the 1990 HMDA data (Canner and Smith (1991)) found that the denial rate for black applicants for conventional mortgage loans was $26.3 \%$, the Latino rate $18.4 \%$, and the white rate $12.1 \%$. High-income blacks were approved less frequently than low-income whites. This result was consistent with, but did not conclusively prove, discrimination against minority loan applicants. Subsequently, the status of equation (2) as an investigative tool has come under intense scrutiny. Some researchers have interpreted it as a sufficient test of whether discrimination exists in housing credit markets; others have pointed out that the process of obtaining housing credit consists of many individual subprocesses, only one of which ends up as an observation in a HMDA data-set. Evidence of minority disadvantage in equation (2) is consistent with the existence of discrimination in the residential credit decision, but does not prove it; on the other hand, evidence of no minority disadvantage in equation (2) - while it suggests the absence of discrimination in the residential credit decision -- says nothing about whether overall housing-credit market processes are race-neutral. Benston (1995), for example, argues that equation-(2) studies are biased toward the finding of "invidious" discrimination, while omitting data such as credit and employment history that may affect decision-making.

A study by the Federal Reserve Bank of Boston (Munnell et al. 1992) set new standards of rigor in implementing equation-(2) models. Boston bank lenders provided researchers with

${ }^{25}$ Contemporary redlining analyses are being used and interpreted in just this way. For example, informative annual assessments of mortgage lending in Boston are conducted for the Massachusetts Community and Banking Council. The MCBC has an equal number of community and bank members; and these annual assessments provide benchmarks that inform discussions about trends in community reinvestment. See Campen (1998). 
complete access to their case files on 1990 home-mortgage applicants, allowing a full accounting of applicant creditworthiness based on the information available to banks.

Probability of loan denial for a given applicant pool = f(Individual economic variables
considered by banks, Individual social variables considered by banks, Individual's race,
Area economic variables considered by banks, Area social variables [including area
race])

Equation (2a) differs from equation (2) in that the researchers have some confidence that they are using precisely the variables considered by the banks whose lending data they are evaluating. These authors found that African American applicants had a 60\% greater chance of loan denial than equally creditworthy whites.

For many analysts, this result was the statistical "smoking gun" showing that banks do discriminate by race. Nonetheless, critics have subsequently challenged this study's result, following two lines of attack. Some have pointed up methodological flaws such as coding errors, sensitivity to outlying data points, and the exclusion of factors important in bank decisionmaking. Others have challenged the adequacy of equation (2a) itself. Bostic (1996) argues that race effects may operate through other variables, not independently; so he "interacts" the borrower-race variable with variables linked to borrower creditworthiness. The borrower-race variable per se loses significance; some race/creditworthiness variables are statistically significant and suggest minority disadvantage. For Bostic, this suggests that only "marginal" borrowers are subject to racial disadvantage; he is not willing to term this "discrimination."

Rachlis and Yezer (1993) and LaCour-Little (1999), following Maddala and Trost (1982), argue that a single reduced-form equation misspecifies mortgage-market behavior. Several decisions are made in a chronological sequence by applicants and lenders: the applicant selects a lender; the applicant or lender selects a specific mortgage product, the lender approves or denies the application, and then an approved applicant decides whether to accept; and after funding occurs, the borrower decides over the life of the mortgage whether to repay or default. In these authors' view, only a simultaneous-equation approach can accurately depict this process. Oneequation models are likely to overestimate the significance of discrimination due to partialobservability bias. No single-equation model such as (2) is adequately identified if the market processes in which it is embedded might differentially affect the comparison groups (minorities and whites). ${ }^{26}$ Further, discrimination may occur at any of the distinct stages of the mortgage process, not only at the application processing stage highlighted in equation (2).

Courchane and Golan (1999) have a different critique of equation (2). They point out that while this equation implicitly assumes that banks evaluate every borrower independently, on his or her own merits, in reality banks operate differently. They establish benchmark criteria for creditworthiness, and then evaluate applicants in terms of those criteria. Racial discrimination

${ }^{26}$ LaCour-Little (1999) argues that misestimated coefficients can also arise when heterogeneous lender-types and borrower-types are not segregated in advance by modelers. He advocates not only pre-sorting data into such homogeneous categories, but also constructing a panel data set to evaluate dynamic borrower behavior through time. 
then exists if banks evaluate minority applicants more strictly than they do other applicants. In terms of econometric methodology, then, the unordered discrete-choice model that is commonly used is inappropriate; the authors suggest a generalized maximum likelihood estimator that relies on information theory.

Some critics (for example, Brimelow and Spenser (1993)) have argued that equation (2) is irrelevant, because rational banks make loan decisions based on expected default rates. The empirical evidence on mortgage default rates and race is ambiguous; some studies find no significant differences, while others find minority default rates to be higher. ${ }^{27}$ If lenders practiced personal discrimination in mortgage markets, they must be forgoing good risks, and minority mortgagees should have lower default rates than white mortgagees. Since the empirical evidence does not support this conclusion, it follows, lenders are not discriminating. ${ }^{28}$

Both lines of criticism have been answered. Ross (2000) synthesizes the ideas that a simultaneous-equation approach is preferred in modeling credit-market outcomes and that racially-differential default rates can be used to evaluate the presence or absence of preferencebased discrimination. He argues, following Heckman (1976), that a 'two step' process incorporating (in this case) both the loan application and the loan-default step would best capture the presence or absence of personal discrimination by lenders. Ross attempts to overlay data collected separately for home-loan applications (using 1990 Boston) and for defaults (FHA data for Boston drawn from 1992) to estimate a two-step model of underwriting and default. ${ }^{29}$ Unfortunately, no clear empirical results regarding the lending decision are obtained in this paper.

Carr and Megolugbe (1993) and Browne and Tootell (1995) take a different approach. These authors counter the methodological criticisms of the Boston study point-by-point, and

${ }^{27}$ Quercia and Stegman (1992) and Goering (1996) review this literature. Berkovec et al. (1994), an especially influential study which uses a random sample of FHA loans originated in 1987 and 1988, finds higher minority default rates. Han (2004) uses the Berkovec et al data set and comes to the same empirical conclusion regarding minority default rates.

${ }^{28}$ Offsetting any incidence of higher default rates is the fact that minority borrowers generate significantly lower levels of prepayment risk than do white borrowers. Kelly (1995) finds, however, significant racial and ethnic differences in mortgage prepayment rates on the basis of VA loans made in the 1971-89 period. After controlling for differences in mobility and in other borrower characteristics, African American homeowners still have a significantly lower rate of prepayments.

${ }^{29}$ The mention of Heckman's work on specification problems brings up another point. It is by no means clear what the multiple equations that should be modeled are, in the case of racial differentials in the mortgage credit market. It may be that lenders are choosing different terms and conditions based on anticipated default rates that differ systematically by race. But the two articles summarized in foonote 15 suggest that minorities are much less likely to apply for credit than are whites, due to a fear of being turned down. This suggests another sort of specification problem - the failure to model separately the borrower's decision to apply as well as the lender's decision to accept. If likely default rates are considered by lenders as well, we are now confronted with a more complex estimation challenge, at the various least. 
demonstrate that this study's central conclusion is robust. ${ }^{30}$ Galster (1993) counters the defaultrate critique; he argues if lenders do not discriminate, and if at the same time minorities face discrimination in markets other than the credit market, then minorities' ex post default rate on mortgages should be higher than whites'. "Galster assumes that "rational discrimination" is illegal; as noted above, this assumption is not universally shared. Ross and Yinger (1999a) do a complete review of the Boston study and the criticisms thereof; these authors examine these criticisms, and sometimes re-estimate equations. They find first that the large racial gap in loan denial cannot be attributed to misspecification or data problems; and they find, second, that no study has demonstrated either the presence or the absence of disparate treatment discrimination or disparate impact discrimination in loan approval. These same authors undertake a thorough critical review of this discrimination literature (1999b). Their review encompasses the new literature on the use of default rates to detect discrimination; they agree with Galster that this approach is fundamentally flawed.

The advent of the Boston Fed study by no means put an end to research on access to housing credit using equation (2). HMDA data, when supplemented with data pertaining to applicant creditworthiness, even if it falls short of the Boston study's standard -- does identify patterns of racial inequality in residential credit markets. ${ }^{32}$ These patterns indicate that structural or personal discrimination, or both may be present. Myers and Chan (1995) have experimented with instrumental-variable techniques as a way of identifying the presence of discriminatory credit standards. Dymski (1999) has used equation-(2) to conduct comparative analyses of outof-state banks, large banks, small banks, and non-banks in various credit markets. Dymski (2001) and Dymski and Mohanty (1999) used an equation-(2) model to compare the degree of racial disadvantage of Asian-American, Latino, and African American applicants in several metropolitan credit markets, over a multi-year time-span; Reibel (1997, 2000) uses equation-(1) and equation-(2) models to explore the problem of neighborhood disinvestment. Many such

${ }^{30}$ Similiarly, Glennon and Stengel (1994) experiment with different regression specifications, and find that this study's empirical conclusions are robust.

${ }^{31}$ Berkovec et al. also test for differences in default rates by neighborhood racial composition, and find no evidence that mortgages in minority neighborhoods have higher default rates. These authors, like Galster, regard the use of higher minority default rates, when unsupported by observable borrower economic characteristics, as illegal. Also see Ross and Yinger (1999c). Ferguson and Peters (1995) use a simple model of bank lending to show that if minority applicants are less creditworthy on average than white applicants, then it cannot simultaneously be true that minorities both have higher default rates and higher loan denial rates -- that is, the conceptual arguments behind the two empirical attacks on the Boston study are inconsistent (given the premise of lower minority creditworthiness).

32 The advent of application-level HMDA data has, however, thrown into question the status of studies of redlining. Tootell (1996) found, for example, that "redlining" effects largely dissipated once racial-discrimination effects against borrowers were accounted for in the Boston data set. In other words, any apparent discrimination against areas with many minority borrowers could be attributed in this case to discrimination against minority borrowers; there was no independent discrimination against areas per se. Other studies of other cities, however, have found statistically significant redlining effects even after borrower race is accounted for (see Dymski (1999)). 
studies have been done, and are being done, for local markets by academic and activists. Such studies do not attempt to establish which lenders are behaving with explicit racial bias; they are efforts to unearth the broad patterns of inequality in credit flows. They establish benchmarks that can inform policy interventions.

Audit studies. The Boston Fed study sets a high standard for empirical models based on equation (2); researchers without that study's access to bank files will be hard-put to avoid the charge of omitted-variable bias. And for some economists, even well-designed regression studies showing that race affects loan decisions cannot prove that lenders use applicants' race in their decision-making.

Audit studies of bank behavior, by contrast, can demonstrate bankers' racial bias to these skeptics' satisfaction. ${ }^{33}$ Audit studies are suited to detecting personal discrimination because they provide direct evidence and thus avoid the objection that observed racial differences are due to unobserved, unmeasured causes. This is not to suggest that audit studies are beyond criticism; as Calem and Longhofer (2002) point out, audit methodologies (like regression analyses of the determinants of credit flows or of the probability of loan denial) also have interpretive limitations.

The Federal Reserve and the Office of the Comptroller of the Currency have conducted numerous audit studies of banks' loan files in the course of making fair lending determinations. These studies have sometimes found evidence of racial bias. Pilot studies conducted by these agencies in Louisville, Chicago, and New York have examined the pre-application stage and found subtle differences in the treatment of black and white testers. Lending officers were more likely to steer, switch, or discourage minority applicants. Minorities were not given "helpful hints," as were whites; and their financial ratios, when marginal, were interpreted negatively (unlike whites'). ${ }^{34}$

The federal Department of Housing and Urban Development (HUD) recently conducted its own exploratory audit study of racial/ethnic bias in the Los Angeles and Chicago mortgageloan markets (Austin Turner, Freiberg, et al., 2002). This study, conducted in 2000, examines various steps that lending institutions and their representatives normally take in the multi-phase process of applying for and precuring a loan. It finds that that most minority home-loan-seekers receive the same treatment as whites. However, a significant minority of black and brown applicants were subject to various kinds of disparate treatment: less coaching and more encouragement to consider an FHA loan (blacks in Los Angeles); less information about loan amount and house price, less product information, less followup (Latinos in Los Angeles, blacks in Chicago); lower loan amounts, less product information, less coaching (Latinos in Chicago).

Small-business credit markets and discrimination. Nothing like HMDA exists for small-business loans. Data on loan levels have been submitted by some lenders under the new

\footnotetext{
${ }^{33}$ In an "audit" study, white and minority subjects pose as housing- and/or credit-market applicants, and then carefully record their experiences. The testers' contacts must be randomized and their experiences standardized to allow data collection. Cloud and Galster (1993) review audit studies.

34 These studies' methodologies and substantive conclusions are discussed by Dietrich (2001).
} 
CRA rules since 1996 and 1997. Initial studies of these data, conducted for a Federal Reserve Bank of Chicago conference in 1999 (Canner (1999), Squires and O'Connor (1999), and Immergluck (1999)) find evidence suggesting that loans for small businesses are substantially less in lower-income and high-minority areas. However, limitations in data collection make it impossible to reach a definite conclusion about what forms of discrimination may be present.

Fortunately, various federal agencies also conduct periodic surveys of business owners. The samples collected are large enough to permit some comparisons on the basis of race. A few studies have used these data to explore the links between racial discrimination and small business activity. Grown and Bates (1992), using the Census Bureau's Characteristics of Business Owner survey for 1987, find that African American-owned construction firms are less well capitalized than other firms, and less likely to survive; banks make smaller loans to African Americanowned construction firms, even taking firm characteristics into consideration. Bates' subsequent studies $(1994,1997)$ show that minority-owned businesses generally receive less credit than other businesses; African American businesses, in particular, have substantially less financial resources and access to banking services than do other firms.

Three recent studies have conducted formal econometric tests for racial discrimination in credit markets used by small businesses. Cavalluzzo and Cavalluzzo (1998) use data from the 1988-89 National Survey of Small Business Finances to analyze the presence of discrimination in the credit markets serving small businesses. These authors find that African American-owned firms are two-and-a-half times as likely to be denied loans, and approximately 13 percent less likely to hold loans. Logit analysis of the probability of denial for those who applied for credit finds that denial rates for African American and Latino-owned firms are 35 percent higher than for other firms, all else equal. They find little evidence that such businesses pay higher interest rates.

Blanchflower et al. (2003), in turn, use data from the 1993 and 1998 versions of the same survey to analyze the existence of credit-market discrimination against African American-owned small businesses. These authors use regression analysis to show that even after controlling for differences in creditworthiness, African Americans are twice as likely as whites to be denied credit for their small businesses. Further, in contrast to the previous study, African Americans pay higher interest rates. These results for 1988-89 and for 1993 and 1998 are broadly consistent with the existence of discrimination. Cavalluzzo, Cavalluzzo, and Wolken (2002), in turn, augment the 1993 data for the National Survey of Small Business Finances with data on local bank market structure and on firm credit-risk scores (drawn from Dun and Bradstreet data). This 2002 paper augments the results obtained in the other two papers by taking into consideration selection bias (per Heckman (1979)), differential firm risk, and bank market structure. The racial disparities in access to credit and in interest rates paid remain even after controlling for these effects. Indeed, the more competitive the market, the less are the observed racial disparities.

\section{Discrimination, Predatory Lending, and Financial Evolution}

Some research has begun to suggest that industrial organization aspects of banking and lending-market behavior may significantly affect credit-market processes and outcomes, and thus may significantly affect empirical results obtained from investigations of discrimination and/or 
redlining. The banking industry is in the midst of a fundamental reorganization of banking structures and practices. This reorganization, needless to say, has affected the extent and character of loan-market discrimination.

An ongoing merger and consolidation wave has seized the industry: failing savings and loan associations have merged or been bought out by banks, and smaller banks have been swallowed by larger competitors. This trend has been driven by intensified competition, which has also led banks to segment their customer markets: instead of offering uniform services to all depositors, banks are increasingly catering to "upmarket" deposit and loan customers, while either shedding lower-balance customers or forcing them to pay high marginal rates. ${ }^{35}$ Further, banks are systematically closing branches, especially in lower-income neighborhoods. Since minority communities and individuals are disproportionately found in the markets that banks are shedding, these shifts increase structural discrimination.

Another shift involves the increasing prominence of secondary markets; some lenders will only originate mortgage loans they can sell off. Secondary-market criteria may have a systematically disparate racial impact, since the wealth ratios and cash-flow measures they stress are lower for minorities than for whites.

In an equation-(2) case study, Kim and Squires (1995) find that the approval rate for black applicants increases with the lender's percentage of minority employees, ceteris paribus. These authors suggest adding other lender characteristics as explanatory variables, including branch locations, counseling availability, and bank marketing practices.

A few studies have scratched the surface of these issues. In a study of an Indiana county, Nesiba (1995) has found that mergers significantly affected credit flows and the extent of redlining in the 1985-93 period. In two studies of Los Angeles, Pollard (1996) and Dymski and Veitch (1996) find that the reorganization of bank functions and bank mergers have significantly affected credit flows and bank branch locations. And Dymski and Veitch (1994) find that area and individual race coefficients are larger (that is, indicate a higher probability of discrimination) for loans sold off to the secondary market than for other loans, in a study of 1990-92 data for Los Angeles. Dymski (1999, Chapter 10) finds that the probability of loan approval varies inversely with the degree of banking-market concentration, in an equation-(2)-type model that controls for applicant race and gender.

The emergence of predatory lending. In the past four years, a new form of discriminatory credit has come into focus: the subprime or "predatory" lending market. This market appears to be a relatively new phenomenon in American credit markets. It refers to loans made on the basis of household or business collateral, under terms and conditions that are exculpatory. ${ }^{36}$ These loans often lead to excessive rates of household and firm non-payment, and

\footnotetext{
${ }^{35}$ For further discussion of shifting bank strategies and patterns in bank consolidation, see Dymski (1999).

${ }^{36}$ Staten and Yezer (2004) point out, in a special issue of the Journal of Real Estate Finance and Economics on subprime lending, there is no commonly-accepted definition of predatory lending. Engel and McCoy (2002) suggest that three categories of mortgage loan be differentiated: prime,
} 
thus to foreclosures and personal financial distress. Certainly, usury has been a fine art in credit markets since the dawn of modern commerce. But a new term seems warranted for this form of lending for several reasons. First, it involves two distinctive sets of practices. One is the aggressive telemarketing and sale of second mortgages based on demographic targeting especially, the targeting of minority households that have traditionally been denied access to credit. ${ }^{37}$ The second is the payday loan - the practice of advancing workers a portion of the money they stand to earn from their paychecks. Payday loans have become common in checkcashing stores. In both cases, financing is often provided by large bank holding companies.

Both these practices have heavily impacted the elderly, people of color, and minority neighborhoods. Hence, the question of discriminatory intent or impact arises. Many low-income and minority borrowers are obtaining loans at high interest rates and with very unfavorable terms from housing-related and payday lenders (Williams (1999). For example, Canner et al. (1999, page 709) found that in 1998, subprime and manufactured housing lenders accounted for 34 percent of all home purchase mortgage applications and 14 percent of originations. These lenders' impact on low-income and minority individuals is even more pronounced. According to Canner et al., in 1998, subprime and manufactured housing lenders made a fifth of all mortgages extended to lower-income and Latino borrowers, and a third of all those made to African American borrowers. According to ACORN (2000), subprime lending grew 900 percent in the period 1993-99, even while other mortgage lending activity actually declined. A nationwide study of 2000 HMDA data by Bradford (2002) found that African Americans were, on average, more than twice as likely as whites to receive subprime loans, and Latinos more than 40\%-220\% more likely. ${ }^{38}$ This evidence suggests that lower-income and minority borrowers are being targeted by these specialized - and often predatory - lenders.

Industrial organization considerations, which are increasingly important in understanding discrimination in the mortgage market, also come into play in investigating predatory lending.

legitimate subprime, and predatory. They define predatory mortgage loans as those involving any of five characteristics: "(1) loans structured to result in seriously disproportionate net harm to borrowers, (2) harmful rent seeking, (3) loans involving fraud or deceptive practices, (4) other forms of lack of transparency in loans that are not actionable as fraud, and (5) loans that require borrowers to waive meaningful legal redress." (P. 1260).

37 A November 2001 study of California cities by the California Reinvestment Committee (CRC), using a borrower survey instrument, found that a third of subprime borrowers were solicited by loan marketers, and that minorities and the elderly are targeted in these marketing efforts. These loans often have onerous terms and conditions; in the CRC study, three in five respondents have punitive repayment penalty provisions, while 70 percent saw their terms worsen at closing. Other common abuses include high upfront fees and costly lump-sum credit insurance.

${ }^{38}$ Also see United States HUD (2000) and the extensive statistics in ACORN (2000). The Department of Housing and Urban Development, together with the Treasury Department, published a study that both discusses the core issues raised by subprime lending and reports on the results of several public forums and task forces (Joint Task Force, 2000). A report by Pennington-Cross, Yezer, and Nichols (2000) challenges the idea that subprime lending has indeed grown in recent years, and goes on to challenge the idea that these loans are exploitative. The points made in this report are rebutted by Immergluck (2000). 
Mergers and changing practices in consumer finance have led to ever more interpenetration between major banking corporations, finance companies, and predatory lenders. ${ }^{39}$ This may be linked to the shift in consumer finance toward a new revenue model: higher fees, paid upfront, for loans made on the basis of attachable assets. Since homes are most households' primary asset, especially later in life when mortgage loans have been paid down, the growth of the subprime mortgage lending market is readily grasped. The logic of the payday loan industry is very similar - next month's paycheck is sufficiently certain to serve as a collateral anchor for this new form of lending.

The subprime lending industry has exploded into prominence in the past several years because of the development of new technologies of securitization and risk-pooling. Henriques and Bergman (2000) report that many of the largest investment banks on Wall Street have been channeling an increasing amount of funds to subprime lenders (an average of $\$ 80$ billion annually in 1998 and 1999); further, some of the most prestigious Wall Street insurers have backed the mortgage-backed securities that subprime lenders have sold off into the markets. The business has grown quickly: one of the worst offenders, First Alliance of Irvine, California, conducted an IPO in 1996. Further, some bank holding companies have purchased subprime lenders. Citicorp acquired Associates First Capital Corporation, which was then under investigation by the Federal Trade Commission and the Justice Department. Associates First represented a step toward Citi's goal of establishing its Citifinancial subsidiary as the nation's largest consumer finance company (Oppel and McGeehan, 2000). This drew an immediate response from fair-lending advocates. For example, Martin Eakes, founder of the non-profit SelfHelp Credit Union in Durham, N.C., commented, "Those of us who have worked on the community level have seen the abuses outlined in the F.T.C. complaint, and many of us believe that Associates is a rogue company and may alone account for 20 percent of all abusive home loans in the nation" (Oppel, 2001). In any event, this consumer-lending subsidiary helped to stabilize Citi's cash-flow during a period in which most megabanks' earnings slumped (Sapsford et al. (2001), Businessweek (2002)).

These emergent practices have already drawn state and federal responses. Congress passed the Home Ownership and Equity Protection Act in 1994; amendments to federal Regulation $\mathrm{Z}$ in 2002, and a variety of state laws (notably those of North Carolina and Pennsylvania) have sought to rein in lenders' abusive treatment of borrowers. A variety of methods are used: heightened disclosure requirements, closer monitoring, limits on interest-rate margin, and/or limitations on the conditions under which these loans can be offloaded or resold, among others.

Academic studies of predatory lending. Most contemporary writing about subprime and predatory lending remains anecdotal. Academic research on predatory lending has only recently begun to emerge. Most of the initial empirical academic studies are collected in two journals' special issues. In both cases, these studies' central focus is on understanding the size and scope of predatory and subprime lending markets, and on the effects of policy interventions into these markets. One of these is volume 29, number 4 of the Journal of Real Estate Finance

\footnotetext{
${ }^{39}$ For example, First Union Bancorp bought the Money Store in June 1998. First Union subsequently closed this unit in mid-2000 in the wake of massive losses (Mollenkamp (2000)).
} 
and Economics, published in 2004; the guest editors' introductory essay is Staten and Yezer (2004). Courchane, Surette, and Zorn (2004) report statistics from a Freddie Mac survey of 8,000 individuals who originated prime and subprime mortgages in 1999 and 2000 . The response rate for this survey was disappointing (14 percent). This survey (like the community-based surveys mentioned above) found that African Americans and Latinos are far more likely to receive subprime loans than are whites. These authors also find that a significant minority of borrowers with subprime loans may have been assigned to this risk pool inappropriately (based in particular on FICA scores). The authors present no statistical evidence about race and inappropriate classification. In turn, Calem, Gillen and Wachter (2004) find in a study of Chicago and Philadelphia that subprime loans are far more likely to be made in minority neighborhoods than elsewhere.

The essays in volume 15, number 3 of Housing Policy Debate also focus substantial attention on the parameters of these emerging markets (McCoy and Wyly (2004)). Two articles (White (2004) and Lax et al (2004)) present empirical results suggesting that subprime lending rates are higher than adjustment for differential borrower risk might justify - suggesting that these markets are inefficient and that many borrowers in these markets are being exploited. Calem, Hershaff, and Wachter (2004) expand greatly on Calem, Gillen and Wachter (2004): seven cities' data are covered; and the distribution of subprime loans is analyzed in the context of controls for neighborhood price risk, individuals' credit risk, and the average educational attainment of neighborhood residents. After all these adjustments are made, there is a positive association between the percentage of African American residents in a neighborhood and the probability that residential loans in that neighborhood will be subprime. This is analogous to redlining - with the difference that previously loans would not be made, but now many more loans will be made, for a price. Terms and conditions on such loans are likely to be more onerous for borrowers than similar loans made elsewhere (Eggert (2004)). Wyly, Atia, and Hammel (2004) show that African American and Latino borrowers have strongly elevated odds of loan rejection in lower-income areas undergoing gentrification, and much higher odds than elsewhere of receiving subprime loans when they are funded.

None of these academic studies has yet established directly that specific minority borrowers are significantly more likely to be sold a subprime or predatory loan than are nonminority borrowers with similar risk profiles. The post-2003 HMDA data should make it possible to conduct such tests. In the meantime, these preliminary studies strongly suggest that such results will be found; at the same time, experience with other models of lending discrimination suggests that results strongly suggesting racial discrimination in the subprime market will hardly put an end to empirical controversy.

\section{Studies of Racial Discrimination in Housing}

As section 4 illustrates, leading credit-market discrimination studies have been conducted by many researchers inside and outside of government. By contrast, the definitive housingmarket discrimination studies have been sponsored largely by HUD, with substantial continuity in core research-team membership. These contrasts can be traced to two factors: first, the absence of anything like an HMDA for housing-market transactions; and second, the reliance of housing-market discrimination research on paired-testing (audit) studies. As Fishbein (1992) 
notes, audit studies are effective means of testing for overt discrimination and disparate treatment.

The Department of Housing and Urban Development has sponsored three audit studies of housing market practices, the Housing Market Practices Survey (HMPS) of 1977, the Housing Discrimination Study of 1989 (1989 HDS), and the Housing Discrimination Study of 2000 (2000 HDS). The HMPS used paired black and white testers in 40 cities, and established audit studies as a viable research methodology. The 1989 HDS, which encompassed 3800 audits in 25 cities, and the 2000 HDS, with 4600 audits in 23 cities, then have provided information of unprecedented depth. Further, these two studies' methodology was designed in such a way as to permit comparisons of the extent of discrimination over time. Austin Turner, Struyk, and Yinger (1991) provide a synthesis of the multi-volume 1989 HDS; the key results for the 2000 HDS are presented in Austin Turner, Ross, Galster, and Yinger (2002). ${ }^{40}$

The 1989 HDS can be used as a benchmark for discussion here. It concluded that $53 \%$ of black renters and 59\% of black homebuyers (as well as $46 \%$ of Latino renters and $56 \%$ of Latino homebuyers) experience discrimination by rental and sales agents: they are not shown available units, are shown fewer units, or are provided with less information and assistance. Further, just over $20 \%$ of both blacks and Latinos are "steered" away from white areas, higher-income areas, and higher-home-value areas. Rental and sales agents were disproportionately located in white neighborhoods, and are much more likely to recommend units in neighborhoods with higher concentrations of minority residents than the metropolitan average. Further, black- and Latinoowned units are less likely to be advertised or to be offered for open house than are white units. Page (1995) uses HDS data to estimate that on average, real-estate agents show African American and Latino housing-seekers 80-90 percent of the units they show to white customers. ${ }^{41}$

The 2000 HDS results differ somewhat from those obtained 11 years earlier. Overall, discrimination against blacks and Latinos remains significant at all stages of the housing search process; but the extent of discrimination is less. In rental markets, the overall incidence of consistent white-favored treatment relative to African Americans dropped from $26 \%$ in 1989 to $22 \%$ in 2000; Latinos' disadvantage increased slightly in these markets from $25 \%$ to $26 \%$. In home-sales markets, the overall incidence of white advantage relative to blacks dropped from $29 \%$ in 1989 to $17 \%$ in 2000; relative to Latinos, the overall incidence of white advantage dropped from $27 \%$ to $20 \%$. This pattern - wherein discrimination against black and brown home-buyers and renters remains significant, but is less in 2000 than 11 years before - holds across all phases of the search process, except for one. That exception is racial steering, which increased substantially in the time-period between the 1989 HDS and the 2000 HDS. The 2000 HDS included pilot investigations of Asian and Native American discrimination were conducted in Phase 1 of 2000 HDS for three test cities - Los Angeles (Southeast Asians), Minneapolis (Koreans and Chinese), and Phoenix (Native Americans). These investigations found evidence that both groups' members are subject to housing-market discrimination.

${ }^{40}$ The 2000 HDS is Phase 1 of a broader investigation that will eventually encompass 60 metropolitan areas and more racial/ethnic categories.

${ }^{41}$ Ondrich, Stricker, and Yinger (1998) and Ondrich, Ross, and Yinger (2000) develop econometric models of discrimination using audit data from the 1989 HDS; using fixed-effects logit techniques, these authors confirm the finding of statistically significant discrimination. 
In both the 1989 and $2000 \mathrm{HDS}$, the attention to survey methodology, comprehensive character of the investigation, and large sample sizes used make these audit studies' findings authoritative. Clearly, many real estate agents are racially biased both in shunning minority clients and in treating the absence of black or brown residents as a locational advantage. The HDS findings do not necessarily suggest that there is a hard core of white real estate agents who overtly dislike or hate minorities, or who are consciously promulgating racial inequities or segregation. More subtle biases could generate the HDS results -- for example, a real estate agent's perception of "good" versus "bad" neighborhoods may be racially coded, regardless of whether that agent intends to disadvantage minorities. In any event, real estate agents might counter charges they are racially biased by noting that whites have very low tolerance for integration in neighborhoods (Massey and Denton (1993, Pp. 92-96)).

Some indirect evidence from two different data sources on trends over time confirms the basic insights about trends in housing discrimination suggested by comparisons of the 1989 and 2000 HDS. Yinger (1997) applies a search model to data from the Panel Study of Income Dynamics, and finds that because of discrimination, African Americans and Latinos pay a premium of approximately $\$ 4,000$ every time they look for a house to buy. Leigh (1992) reviews housing trend data from 1940 to the present. She finds that blacks' relative overexposure to unsafe or overcrowded housing conditions has fallen, and racial disparities in rent levels and in the probability of home ownership have been steadily reduced. Nonetheless, serious racial gaps in housing persist. The percentage of black homeowners has risen substantially; at the same time, the gap between the proportion of white and black homeowners has remained constant at approximately $20 \%$ since 1940 . As Leigh notes, blacks caught up with whites' 1940 homeownership rate only in 1987. Supplementing these results, Stone (1991) finds that blacks are more likely than whites to be in unaffordable or crowded housing.

One immediate consequence of discrimination in housing markets is deepening racial segregation. Austin Turner and Weink (1991) show that US residential segregation is higher than affordability considerations or individual preferences alone would predict; they suggest this "extra" segregation is due to discrimination in housing allocation processes.

However, what sort of discrimination may be at work is difficult to establish. For one thing, the effects of behavioral and structural factors overlap. The disparate treatment of minorities documented in the HDS reduces minority demand for housing in white areas, and decrease the minority-owned housing supply offered to whites. Overt discrimination by realestate agents and residents increases white demand in white areas, and reduces it in mixed areas. At the same time, structural discrimination leads to fewer minorities being able to afford homes. The correlation of minority status with lower incomes, and of minority neighborhoods with lower levels of public investment-what Galster and Keeney (1991) call the "nexus of urban racial phenomena" -- encourages housing-market bias against minority areas.

Leigh (1992) documents the persistence and even growth of racial segregation and isolation: despite black gains in suburbanization, the elimination of racial covenants, and the presence of fair-housing laws, racial segregation and isolation has remained stable or even 
deepened over time. ${ }^{42}$ Massey and Denton (1993) argue that racial segregation, in turn, deepens structural discrimination independent of any other economic dynamics:

With or without class segregation, residential segregation between blacks and whites builds concentrated poverty into the residential structure of the black community and guarantees that poor blacks experience a markedly less advantaged social environment than do poor whites (1993: 125).

\section{Gender Discrimination in the Credit and Housing Markets}

Discussion in sections 2-6 has focused on racial inequality in credit and housing markets. The other protected categories under anti-discrimination laws, including gender and sexualpreference, have not yet become a central focus of controversy among academics and policymakers. This is not to say that housing and credit-market discrimination is not a problem for those in these other protected categories. However, no mechanism for the systematic collection of information exists; most of what is known is at the level of complaints registered at community-based and advocacy organizations. This section discusses gender discrimination in the credit market. No academic work exists on gender discrimination in the housing market, or on sexual preference discrimination in either the credit or housing markets. ${ }^{43}$

As with racial discrimination, the first empirical investigations of gender discrimination in the credit market were undertaken in the mid-1970s. ${ }^{44}$ Edelstein (1977) and Schafer and Ladd (1980) examined gender discrimination in the mortgage credit market. These investigators found sizeable gaps in credit approval for female applicants, but no clear pattern of gender-based discrimination. Little subsequent empirical work on women's access to credit has been done.

Gender-based research has been inhibited by the lack of an analogue to the HMDA; no systematic collection of credit-market data for gender effects has been required under law until $1990{ }^{45}$ While the data collected under HMDA through 1989 permitted indirect examinations of race effects, they could not be used to undertake even indirect examinations of gender effects. HMDA data collected since 1990 do include gender data for both applicants and co-applicants.

${ }^{42}$ The shift of some minorities to suburbs has often led to segregated suburbs, not to integrated ones; indeed, by numerous measures, minorities' geographical isolation has increased (Abramson et al. (1995)).

${ }^{43}$ Literature on the legal aspects of gender discrimination in housing does exist (for example, Smith (2000)), and social activists have begun to organize around these forms of discrimination in the credit and housing markets.

${ }^{44}$ Congressional hearings signalled policy-makers' interest in these questions; a 1974 hearing (U.S. House of Representatives (1974)) focused on gender discrimination in credit markets.

${ }^{45}$ Similarly, there is no gender analogue to the CRA. Note that whereas civil rights law prohibits discrimination on the basis of both gender and race in credit markets, the CRA goes further in that it requires lenders to make pro-active efforts to identify and meet credit-market needs throughout their market areas. There is no explicitly racial content to the CRA's mandate; but given the close correlation between inner-city areas and minority residential areas, this mandate embodies an implicit commitment to identify and meet minority borrowers' needs. 
The empirical work that has been done on the impact of gender on outcomes in residential credit markets has generated ambiguous empirical results. ${ }^{46}$ Avery, Beeson, and Sniderman (1996) conducted a study using 1990-1991 HMDA data across several geographic markets. They found that when women are the primary applicant for home purchase loans, the coefficient is insignificant irrespective of co-applicant status. Moreover, they found that maleonly applications are 2-3 percent more likely to be rejected than female-only applications. Hunter and Walker (1995) similarly found gender insignificant in determining loan approval in Boston. Dymski (1999) includes race and gender dummy variables in a study of 1992-96 home-purchase loan decisions in 23 states' metropolitan areas. He finds that while most of the race variables consistently are statistically significant and negative, the coefficient for female applicant is often insignificant; and when it is significant, it takes on both positive and negative signs.

Sanders and Scanlon (2000) used 1992 HMDA data for St. Louis to test whether women are more likely to be denied home mortgage loans. Their logistic regressions found that gender was significant - however, men were slightly more likely than women to be denied loans. Women who were primary applicants with co-applicants were more likely denied loans than women who applied independently. Mohanty (2001) generated more consistent results for applicant gender by "racializing" the gender variable. Using 1992-98 HMDA data from a variety of California cities, she tested for the impact of being female and African American, female and Latino, and so on, on the likelihood of application approval (with race entered separately for male applications). In her logistic regression results, she finds for most cities that minority women are more likely to be denied loans than other applicants.

The modeling literature of gender effects in credit markets is even less developed than the slim empirical literature. Read (1998) reviews the asymmetric-information literature on borrower-lender relations, and finds it an inadequate vehicle for discussing gender effects both because it doesn't take into account the gender-typed personality and context-that is, history and other circumstances - that differentiate many female business-loan applicants from males. In effect, she identifies factors that might lead to personal or structural discrimination against women who apply for business loans. Dymski (2000) explores the theoretical basis for gender discrimination in credit markets by identifying key structural differences between gender and racial disadvantage. One key difference is that adult females share households with males far more frequently than minority adults; and female-headed households, while they do tend to cluster spatially, are far less segregated than are minority-headed households. When women head households and seek credit, the question of access to credit can be posed as it is for minorityheaded households. When they share households with male adults, any link between gender disadvantage and the credit market operates at the level of social relations within the household. In such households, gender inequality may lead to unfair outcomes, but it is difficult to link these in any simple way to gender-based discrimination in the credit market.

\footnotetext{
${ }^{46}$ A literature on gender aspects of small-business credit market has begun to emerge. This work, which consists of small-scale empirical studies (Buttner and Rosen (1992), Read (1998), finds that credit availability constitutes an important barrier for female business owners, and that a large proportion of female entrepreneurs have felt that gender discrimination has colored their relations with banks.
} 


\section{Social and Spatial Embeddedness and Housing and Credit-Market Outcomes}

The studies discussed thus far implicitly make two profound simplifications. First, they treat credit market and housing market dynamics as isolated topics - whereas in fact these markets' trajectories are tightly interconnected. Second, they assume that any individuals' characteristics can be defined independently of the characteristics of any other individual and of the characteristics of any neighborhood; and similarly for neighborhoods' characteristics. This independence permits a simple portrayal of the housing-choice and loan-decision process: individuals seek to move to neighborhoods; and banks have more or less accurate information about individuals and/or neighborhoods; so individuals and neighborhoods may prosper more or less depending on how lenders process creditworthiness signals.

These simplifications are encouraged implicitly by the literatures on these two markets. For example, once applicant-by-applicant tests of the probability of loan denial became possible, in the eyes of some analysts, credit-flow differentials by neighborhood are redundant or simply irrelevant. Several studies have tried to show that the correlation between area racial composition and lending flows disappears when more variables accounting for risk and economic fundamentals are included. Perle, Lynch, and Horner (1993) use 1982 Detroit data to show while lending flows appear sensitive to area racial composition in an equation-(1) model with four variables, they no longer are in a more fully specified (11-variable) model. Schill and Wachter (1993) take this approach one step further; they use an equation-2 model with 1990 (applicationlevel) HMDA data to study race effects in Philadelphia and Boston. They find that individual race is a consistently significant determinant of loan denial; but while neighborhood racial composition significantly determines loan denial rates in the absence of neighborhood "quality" variables, it becomes insignificant when seven neighborhood "quality" variables (including the percentage of residents on welfare) are added. ${ }^{47}$

Some researchers have questioned these simplifications and pointed the way toward richer models. These models promise to explore deeper consequences of the location of households and businesses in social and physical space, and of the intertwining of their their housing and credit commitments.

The family home is the principal means of saving for most American households; and the mortgage loan on that home is most households' largest single liability. The ability of most households to accumulate wealth depends on whether the home they buy will gain in value, and on what terms and conditions they receive on their mortgage loans. Households' efforts to accumulate wealth on their journeys through space-time are not neutral in race and gender terms. Minorities and women tend to earn less income, all else equal. And these households' homes do not exist in cyberspace, but in real neighborhoods; to own a home is to make a commitment that is irreversible in the very short run, and which exposes the purchasing unit to substantial risk of loss. That is, to own a home is to take on financial fragility; and this financial fragility is inseparable from, and embedded in, the household's geographic locus (and similarly for business

${ }^{47}$ Since neighborhood-characteristics data are collected every ten years, while applicant data vary yearly, econometric comparisons of applicant-vs.-neighborhood effects are biased toward finding neighborhood characteristics irrelevant. 
owners). The unique influence of place in the dynamic trajectory of agents locked into specific communities has been recognized by social scientists, especially sociologists and geographers.

A huge literature explores the links between discrimination and housing segregation; see, for example, Wilson (1987), Massey and Denton (1993), and Kain (1992). This literature investigates how racial segregation and isolation per se reproduce and deepen economic and social inequality. ${ }^{48}$ The options any individual has depends not just on his initiative but on the resources with which she has to work, on the activities and resources of those around her, on the presence or absence of firms, and on these firms' resources and strategies.

These writings point toward a more general phenomenon: the significance of spillovers in social and economic outcomes. What is meant here is not just the informational spillovers that occur when lenders make rational-discrimination characterizations of places within their market areas, but spillovers of knowledge, resources, risk, and so on. "Connections" with relatives or coethnics on the basis of shared blood or nationality are forms of spillover, ties that convert apparently autarchic masses of human beings into clusters of interlinked social honeycombs.

Models that emphasize the importance of inter-agent ties, of networks and of spatial spillover effects on economic outcomes are now emerging, some with the potential to demonstrate the impact of race effects on individual and community welfare. For example, the growing economic geography literature on financial exclusion (for example, Leyshon and Thrift (1995)) emphasizes the interactions among financial intermediary market strategies, credit flows, and race in patterns of uneven urban development.

Some economists have used models with inter-agent spillovers to explain racial discrimination. Calomiris et al. (1994) and Hunter and Walker (1995) argue that if lenders have "cultural affinity" with white borrower applicants, but not with minority borrower applicants, their information costs with whites will be much less that with minorities, and they will make many more loans to whites than to equally creditworthy minorities. ${ }^{49}$ Scalera and Zazzaro (2001) construct a model in which cultural affinity generates consistently inefficient outcomes. They show that persistent and inefficient group discrimination results under these conditions: if the development of any group's entrepreneurial skills are hampered by binding credit constraints, and/or if good firms can migrate elsewhere; if any group's quality changes over time, and if banks estimate group quality on the basis of past observed default rates. There can be permanent losses in an economy with these characteristics.

As with the literature on rational discrimination, it isn't clear whether the "cultural affinity" model is being proposed to criticize or to justify racial inequality in market outcomes. And in any event, pushed too far on its own, this model breaks down. For example, Black et al.

\footnotetext{
${ }^{48}$ Kasarda (1993) documents that inner-city neighborhoods' degree of poverty and segregation has deepened. Galster and Mincy (1993) show that racial composition significantly affected the "changing fortunes" of urban neighborhoods.

${ }^{49}$ Strictly speaking, these authors model cultural affinity between white lenders and white borrowers, not racial antipathy between whites and minorities. However, this comes to the same thing as Becker's racial preferences, especially because cultural-affinity ties arise exogenously.
} 
(1997) show that when the lending patterns of African American-owned and other banks are compared on a consistent basis, African American banks are no less likely to discriminate on the basis of race than are other lenders. These authors argue that this result constitutes yet another demonstration that racial discrimination is less important than some think. This interpretation is debatable on its own terms. ${ }^{50}$ In turn, Ross and Yinger (1999b) interpret these banks' failure to lend more to African Americans as representing a failure of cultural affinity on the part of African American banks. This might be true, if all differences between racial credit-market applicants were eliminated. But this is hardly the case. African American-owned banks often have far weaker balance sheets than do other banks, making them relatively more cautious about loan-making, ceteris paribus.

Arrow (1998) himself recently suggested the importance of inter-agent networks and spillovers in understanding racial discrimination; but he also insisted on the importance of history and institutional context. To have the former without the latter is inappropriate, he writes. Unfortunately, this inappropriate path is precisely the one that has been followed thus far. ${ }^{51}$ This same blind spot is evident in writing on informal financial networks among ethnic minorities. For example, Sowell (1981), among others, celebrates the success of various ethnic groups in using informal financial mechanisms to mobilize their savings, and wonders why African Americans cannot do the same - without taking into account the very special historical circumstances of every group's assimilation/segregation experience in America. Other empirical and theoretical work shows that ethnic network relationships are not the sole determinant of any group's success; instead, structural factors mediate the impact of networks on outcomes. ${ }^{52}$ And for some economists, cultural affinity should not be taken as exogenous, but instead regarded as an endogenous variable about which agents make decisions based on their positional power and their resources (Darity, Mason, and Stewart (1991)); culture, in effect, is an illusory variable (Darity (2002)) which masks the effects of financial and social power.

One measure of this power is racial wealth differentials. Recent evidence (Chiteji and Stafford (2000), Wolff (2001), Barsky et al. (2002)) suggest that these differentials remain

${ }^{50}$ For example, African American-owned banks often have far weaker balance sheets than do other banks, making them relatively more cautious about loan-making - leading to the apparent empirical evidence that they discriminate against African American borrowers as much as do white-owned banks.

${ }^{51}$ Perlmann (1998) writes about the lack of historical and conceptual specificity in discussions of phenomena emphasizing the "cultural affinity" of ethnic minorities in the U.S.

52 Aaronson et al. (2004) examine the data from the National Survey of Small Business Finance that was discussed above, and find that African American-owned firms have fewer close ethnic ties and less geographic proximity, and hence less trade credit, than do other minority firms. Dymski and Mohanty (1999) show that Asian American and African American banks in Los Angeles County have virtually identical records in responding to the needs of their co-ethnic communities; the key difference is in these banks' relative numbers. In effect, the existence of an ethnic network is not the only factor governing a group's success; objective institutional factors also matter. At the level of theory, Leitner (2002) shows that financial networks can be optimal for groups of interlinked agents, as it helps them counter the potential for contagion; however, when these agents' resources are small, the entire network can be liable to collapse. 
profound - some two-thirds are not attributable to income differentials. In other words, these differentials are both the legacy of history and a key binding constraint on agents' future economic activities. For example, racial wealth differentials have a great impact on the availability of credit and the likelihood of success of small business (Avery et al. (1998)). Elmelech and Lu (2004) show that these gaps are even more profound for minority women.

\section{Conclusion}

The literatures on discrimination in the credit and housing markets are compelling, incomplete, contradictory, and controversial. They are compelling because the questions raised are central both in American experience and also in debates over the significance of racial inequality for social policy and social theory. Studies of credit markets in numerous countries now explore logics of discrimination. ${ }^{53}$

They are incomplete first because they cover only a portion of the legal ground protected under the Constitution and the Civil Rights Act. There are virtually no studies of credit-market and housing-market discrimination on the basis of sexual preference; there are few on gender. These literatures are also incomplete because the models developed thus far raise more questions than they answer. Consider the theoretical literature on redlining, for example: why is so little known about redlined neighborhoods, and why is the cost of collecting information there so high? What neighborhood spillovers does lending volume generate? Where do the poorer economic fundamentals of redlined neighborhoods come from? To the extent that theories leave these questions unanswered, they fail to fully confront the historical legacy of racial inequality. These theories offer circular explanations instead: because redlining existed before, less is known about redlined areas and returns there are more variable, so redlining exists today.

These studies are also - necessarily -- contradictory. For one thing, the complementary but not identical legal principles of fairness for individuals (Civil Rights legislation) and fair access for communities (the Community Reinvestment Act) do not jointly identify a clear set of behaviors that infringe on the rights of a well-identified set of protected classes. Some regard an empirical study as successful when it depicts a clear pattern of racial difference in housing and credit flows; others define a study as successful only when it isolates predatory racial behavior which can only be attributed to racial animus. In one reading, then, a huge literature successfully documents many facets of racial inequality in housing and credit markets; in another reading, a huge literature has been unable to conclusively show that a problem exists to be addressed through extra-market means.

Finally, empirical tests for credit and housing discrimination are controversial. This controversy stems in part from honest disagreements among practitioners over the design and interpretation of statistical tests for discrimination. However, the skepticism of some commentators about econometric design is linked to their deeper skepticism about federal legislation in this area. These skeptics have both challenged the efficacy of civil-rights laws and

${ }^{53}$ Simmons and Supri (1999), for example, analyze discrimination in Indian credit markets, and Fukuyama et al. (1999) discuss discrimination in Japan against Korean-owned firms. 
confused the mandates of the ECOA and the CRA. For example, Rachlis and Yezer write that: "the inability to use HMDA or other mortgage flow data in single-equation reduced-form models to test for discrimination in mortgage models are well known. Unfortunately, time and effort are still devoted to such seriously flawed analysis" (1993: 324). Reading further shows that, for these authors, these "flaws" consist not just in econometric problems, but in the legal context of discrimination law. They go on to write that "current definitions of discrimination in law and regulation are far too simplistic and vague to deal with the complex econometric issues that would be encountered should serious litigation ... be focused on the problem of ... testing for differential treatment" (Rachlis and Yezer 1993: 332).

Ronald Weink, formerly President Reagan's special assistant for fair lending at the Comptroller of the Currency, agrees; he argues that regulators should use audit studies of bank procedures and bankers to detect discrimination in credit markets, because assessments based on HMDA data will have them "looking [for discrimination] in the wrong places" (1992, page 227). In this same paper, Weink admits he "could never quite define 'fair lending' or 'equal credit opportunity" " while in office. Lacker (1995), another critic of econometric tests of credit markets, is similarly confused about the law. He cites a federal prohibition of "discrimination against neighborhoods," thus confusing the legal injunction against discrimination in credit markets (embodied in the 1974 ECOA) with the Congressional mandate that depositories reinvest in neighborhoods.

This pairing of a critique of civil-rights law and econometric methodology is relatively rare. Most economists who worry about the econometric design of tests for discrimination accept the need to police racial perpetrators. Nonetheless, this leads not to a profession-wide agreement on the need to conduct econometric studies that might identify discriminatory trouble spots, but instead to the sort of ambivalence that has been evident throughout our discussion. Most analysts would accept the view that overt discrimination and disparate treatment are illegal in that they reflect abuses by racial perpetrators. Some who hold this view then insist that econometric techniques are sufficient only if they serve to identify perpetrators in deed and in intention; others suggest a lower threshhold for econometric evidence should be used.

For example, Galster (1992) praises the (1992) Boston study as thorough, and argues that it uncovers disparate-treatment discrimination. But Galster tempers his praise, warning that equation-(2) studies conducted without access to bank loan files cannot detect discrimination. Omitted-variable bias is a "fatal shortcoming," since "crucial control variables such as credit and employment histories, indebtedness, and assets and characteristics of the property" (1992: 650) are missing. Glennon and Stengel (1994) argue that since the controversial Boston study "represents only one study, in one city, at one point in time," it should be replicated elsewhere. But this qualified call for more Boston-type studies is itself problematic. As these authors observe, "the intense publicity and controversy generated by the release of the Boston Fed study" make it "virtually certain that such a follow-up effort will never take place" (Glennon and Stengel 1994: 36). Lenders are unlikely to cooperate as they did in Boston. Does this make innocent bystanders of all the economists who claim to be interested in discrimination in these markets, but who lack the ability to do the intensely detailed analysis of credit-market decisions that was possible on a one-time basis in one city? 
So what about HMDA-based studies that lack the comprehensive character of the Boston study? Stengel and Glennon (1995) cautiously affirm equation-(2) studies. These authors used four anonymous banks' loan files to construct "Boston-style" equations; they then compared this indirect evidence of disparate treatment discrimination with confidential case-file audits conducted by the Comptroller of the Currency. They find that while differences in bank structure make it impossible to draw precise conclusions from regressions, regression evidence is a useful diagnostic tool for deciding when to conduct deeper inquiries into discriminatory practices. ${ }^{54}$

So there is no critique-proof methodology for assessing the presence or absence of discrimination. More refined or detailed empirical tests with improved HMDA data are unlikely to put all criticism to rest. As we have seen, audit studies too, as tools for identifying racial perpetrators, have their advocates and their critics. What about the legal injunction against disparate impact? This injunction, which is embodied in Civil Rights law, goes beyond the boundaries of what many economists consider acceptable - that is, to inherited, sociallydetermined economic imbalances in wealth and resources. The empirical research cited in the previous section proves that these inheritances, these social divides, are profound and extensive. They are not remediable by shifts on the margin in market outcomes, though these might help.

And this leaves many economists, insofar as they want to consider issues of racial and gender inequality and social justice, with a dilemma. The focus of professional interest has increasingly centered on whether racial perpetrators can be caught in the act. But while racial perpetrators certain worsen the extent of racial and gender difference in credit- and housingmarket outcomes at the margin, existing structural divides in resources and wealth do most of the damage. That is, the professional focus is on one portion of a multidimensional, through-time process -- that portion which is hardest to identify precisely - while the remainder of the process remains outside the view-range of the analytical binoculars.

So the problem of discrimination is seen through a glass darkly. Why shouldn't economic debate begin, not by presupposing a state of nature in which ex ante structural racial/gender inequality do not exist, but instead by acknowledging analytically the historical legacy of racial and gender inequality. The latter is, after all, inherited from America's history. Is economics afraid of history? If not, why not develop a theory more appropriate for the legal context and historical basis of the nation's laws against discrimination? So much work has been done on the economics of discrimination in credit and housing markets. But so much work, and so many challenges, remain.

\footnotetext{
${ }^{54}$ But this is precisely what some participants in this debate deny. Yezer, for example, reacts to the new CRA-based studies of small-business finance as follows: "all of the problems inherent in the use of HMDA data to test for mortgage lending discrimination also apply to business lending. ... implied statistical analysis of the data on business lending under the new CRA data requirements cannot demonstrate the presence or absence of discrimination. Proposals to supplement the business lending data, including demographic characteristics of the owner(s) and adding information on applications, will produce a data set whose only use is to produce false positive indications of lending discrimination" (1999, P. 88). The idea that the "only use" of these data is to draw inappropriate conclusions is far from a consensus among researchers.
} 


\section{Bibliography}

Abramson, Alan J., Mitchell S. Tobin, and Matthew R. VanderGoot, "The Changing Geography of Metropolitan Opportunity: The Segregation of the Poor in US Metropolitan Areas," Housing Policy Debate 6(1), 1995. Pp. 45-72.

Aaronson, Daniel, Raphael Bostic, Paul Huck, and Robert Townsend, "Supplier Relationships and Small Business Use of Trade Credit," Journal of Urban Economics 55(1), January 2004, Pp. 46-67.

Ahlbrandt, Jr., Roger S., "Exploratory Research on the Redlining Phenomenon," Journal of the American Real Estate and Urban Economics Association, Winter 1977.

Arrow, Kenneth, "The Theory of Discrimination," in Discrimination in Labor Markets. Edited by Orley Ashenfelter and Albert Rees, Princeton: Princeton University Press, 1971. Pp. 3-33.

Arrow, Kenneth J., "What Has Economics to Say about Racial Discrimination?” Journal of Economic Perspectives, 12(2), Spring 1998, Pages 91-100.

Association of Community Organizations for Action Now (ACORN), Separate and Unequal: Predatory Lending in America. Sacramento, CA: California ACORN, October 31, 2000.

Austin Turner, Margery, Michael Fix, and Raymond J. Struyk, Opportunities denied, opportunities diminished. Urban Institute Report 91-9. Washington, DC: Urban Institute Press, 1991.

Austin Turner, Margery, Fred Freiberg, Erin Godfrey, Carla Herbig, Diane K. Levy, and Robin R. Smith, All Other Things Being Equal: A Paired Testing Study of Mortgage Lending Institutions - Final Report, April 2002. Washington, DC: Urban Institute.

Austin Turner, Margery, Stephen L. Ross, George C. Galster, and John Yinger, Discrimination in Metropolitan Housing Markets: National Results from Phase I HDS 2000 -- Final Report, November 2002. Washington, DC: Urban Institute.

Austin Turner, Margery, and Felicity Skidmore, Editors, Mortgage Lending Discrimination: A Review of Existing Evidence. Washington, DC: Urban Institute, June 1999 (1999a).

Austin Turner, Margery, and Felicity Skidmore, "Introduction, Summary, and Recommendations,” in Austin Turner and Skidmore (1999a). Pp. 1-22 (1999b).

Austin Turner, Margery, Raymond J. Struyk, and John Yinger, Housing discrimination study: synthesis. Washington, DC: U.S. Department of Housing and Urban Development, 1991.

Austin Turner, Margery, and Ronald Weink, "The Persistence of Segregation: Contributing Causes," mimeo. Washington, DC: Urban Institute, 1991.

Avery, Robert B., Patricia E. Beeson, and Mark S. Sniderman, “Accounting for Racial 
Differences in Housing Credit Markets." in Mortgage Lending, Racial Discrimination, and Federal Policy eds. John Goering and Ron Weink. Urban Institute Press, 1996.

Avery, Robert B., Raphael W. Bostic, and Katherine A. Samolyk, "The Role of Personal Wealth in Small Business Finance," Journal of Banking and Finance 22, 1998, Pp. 1019-61.

Barsky, Robert, John Bound, Kerwin Charles, and Joseph Lupton, "Accounting for the BlackWhite Wealth Gap: A Nonparametric Approach," Journal of the American Statistical Association 97, Issue 459, September 2002, Pp. 663-73.

Barr, Michael S., "Banking the Poor,” Yale Journal on Regulation 21, 2004, Pp. 121 -.

Bates, Timothy M., “An Analysis of Korean-Immigrant-Owned Small-Business Start-Ups with Comparisons to African American and Nonminority-Owned Firms," Urban Affairs Quarterly 30(2), December 1994, Pp. 227-48.

Bates, Timothy M., Race, Self-Employment, and Upward Mobility: An Illusive American Dream. Baltimore: Johns Hopkins University Press, 1997.

Becker, Gary S., The Economics of Discrimination. Chicago: University of Chicago Press, 1957.

Becker, Gary S., The Economics of Discrimination. Second edition. Chicago: University of Chicago Press, 1971.

Becker, Gary S., “The Evidence Against Banks Doesn't Prove Bias,” Business Week, April 19, 1993, P. 18.

Bell, Derrick, Race, Racism, and American Law. Boston: Little, Brown and Company, 1980.

Benston, George, "Mortgage Redlining Research: A Review and Critical Analysis," Journal of Bank Research, 12, 1981. Pp. 8-23.

Benston, George, "The History and Value of HMDA Data for Studies of Invidious Discrimination," Fair Lending Analysis: A Compendium of Essays on the Use of Statistics. Washington, DC: American Bankers' Association, 1995.

Berkovec, James, Glenn Canner, Stuart Gabriel, and Timothy Hannan, "Race, Redlining, and Residential Mortgage Loan Performance," Journal of Real Estate Finance and Economics 9(3), November 1994, Pp. 263-94.

Black, Harold A., M.C. Collins, and K.B. Cyree, "Do Black-Owned Banks Discriminate Against Black Borrowers?” Journal of Financial Services Research 11(1-2), February 1997, Pp. 189-204.

Blanchflower, David G., Phillip B. Levine, and David J. Zimmerman, "Discrimination in the Small Business Credit Market," The Review of Economics and Statistics, 85(4), November 2003, Pp. 930-943. 
Bostic, Raphael W., "The Role of Race in Mortgage Lending: Revisiting the Boston Fed Study," Division of Research and Statistics Working Paper. Washington, DC: Federal Reserve, December 1996.

Bradbury, Katherine L., Karl E. Case, and Constance R. Dunham, “Geographic patterns of mortgage lending in Boston, 1982-87," New England Economic Review (September/October 1989). Pp. 3-30.

Bradford, Calvin, Risk or Race? Racial Disparities and the Subprime Refinance Market. A Report of the Center for Community Change. Washington, DC: Center for Community Change, May 2002.

Bradford, Calvin, and the Urban-Suburban Investment Study Group, "Redlining and disinvestment as a discriminatory practice in residential mortgage loans," Center for Urban Studies, University of Illinois. Washington, DC: Department of Housing and Urban Development, Office of the Assistant Secretary for Fair Housing and Equal Opportunity, 1977.

Brimelow, Peter, and Leslie Spenser, “The Hidden Clue,” Forbes, January 4, 1993.

Browne, Lynn E., and Geoffrey M.B. Tootell, "Mortgage Lending in Boston -- A Response to the Critics," New England Economic Review, September/October 1995. Pp. 53-78.

Businessweek, "The Beseiged Banker,” April 21, 2002.

Buttner, E. H., and B. Rosen, "Rejection in the Loan Application Process: Male and Female Entrepreneurs' Perceptions and Subsequent Intentions," Journal of Small Business Management 30(1), 1992, Pp. 58-65.

Calem, Paul S., and Stanley D. Longhofer, "Anatomy of a Fair-Lending Exam: The Uses and Limitations of Statistics," Journal of Real Estate Finance and Economics 24(3), May 2002, Pp. 207-37.

Calem, Paul S., Kevin Gillen, and Susan Wachter, "The Neighborhood Distribution of Subprime Mortgage Lending," Journal of Real Estate Finance and Economics 29(4), 2004, Pp. 393-410.

Calem, Paul S., Jonathan E. Hershaff, and Susan Wachter, "Neighborhood Patterns of Subprime Lending: Evidence from Disparate Cities," Housing Policy Debate 15(3), 2004, Pp. 60322.

California Reinvestment Committee, Stolen Wealth: Disparities in California's Subprime Lending Market. San Francisco: California Reinvestment Committee, November 29, 2001.

Calmore, John O., "Race/ism Lost and Found: The Fair Housing Act at Thirty," University of Miami Law Review 52, July 1998, 1067-1130. 
Calomiris, Charles W., Charles M. Kahn, and Stanley D. Longhofer, "Housing-Finance Intervention and Private Incentives: Helping Minorities and the Poor," Journal of Money, Credit, and Banking 26(3, Part 2), August 1994. Pp. 634-74.

Campen, James, Changing Patterns V: Mortgage Lending to Traditionally Underserved Borrowers and Neighborhoods in Greater Boston, 1990-97. Boston: Massachusetts Community and Banking Council, 1998.

Canner, Glenn, "Redlining and Mortgage Lending Patterns," Research in Urban Economics, 1, 1981. Pp. 67-101.

Canner, Glenn B., "Evaluation of CRA Data on Small Business Lending," in Business Access to Capital and Credit. Chicago: Federal Reserve Bank of Chicago, 1999, Pp. 53-84.

Canner, Glenn B., Wayne Passmore, and Elizabeth Laderman. "The Role of Specialized Lenders in Extending Mortgages to Lower-Income and Minority Homebuyers." Federal Reserve Bulletin, November 1999, Pp. 709-723.

Canner, Glenn, and D. Smith, "Home Mortgage Disclosure Act: expanded data on residential lending," Federal Reserve Bulletin, 77, November 1991. Pp. 863-864.

Caplovitz, David, The Poor Pay More. New York: The Free Press, 1967.

Carr, James H., and Isaac F. Megbolugbe, "The Federal Reserve Bank of Boston study on mortgage lending revisited," Journal of Housing Research 4(2), 1993. Pp. 277-314.

Caskey, John, Fringe Banking: Check-Cashing Outlets,Pawnshops, and the Poor (New York: Sage, 1994).

Cavaluzzo, Ken S., and L.C. Cavalluzzo. 1998. "Market Structure and Discrimination: The Case of Small Business." Journal of Money, Credit, and Banking 30(4): 771-792.

Cavalluzzo, Ken S., Linda C. Cavalluzzo, and John D. Wolken, "Competition, Small Business Financing, and Discrimination: Evidence from a New Survey," Journal of Business 75(4), 2002, Pp. 641-80.

Chiteji, Ngina, and Frank P. Stafford, "Asset Ownership Across Generations," Working Paper No. 314. Annandale-on-Hudson, N.Y.: Jerome Levy Economics Institute of Bard College, September 20

Cloud, Cathy, and George Galster, "What Do We Know About Racial Discrimination in Mortgage Markets?" Review of Black Political Economy, 22(1), Summer 1993. Pp. 101120.

Courant, P., "Racial Prejudice in a Model of the Urban Housing Market," Journal of Urban Economics, 5, 1978. Pp. 329-45.

Courchane, Marsha J., and Amos Golan, "Estimation and Evaluation of Loan Discrimination An Informational Approach," Working Paper, Department of Economics, American 
University, January 25, 1999.

Courchane, Marsha J., Brian J. Surette, and Peter M. Zorn, "Subprime Borrowers: Mortgage

Transitions and Outcomes," Journal of Real Estate Finance and Economics 29:4, 2004, Pp. 365-92.

Cronin, Francis J., "Racial Differences in the Search for Housing," in Modeling Housing Market Search. Edited by William A.V. Clark. New York: St. Martin's Press, 1982. Pp. 81-105.

Crook, Jonathan, “Who is discouraged from applying for credit?" Economics Letters 65, 1999, Pp. 165-72.

Darity, Jr., William, "Intergroup Disparity: Why Culture Is Irrelevant," mimeo, Department of Economics, University of North Carolina, Chapel Hill, April 2002.

Darity, Jr., William A., Patrick L. Mason, and James B. Stewart, "Race, Class, and the Economics of Identity: A Theory of Racism," mimeo, Department of Economics, Florida State University, February 2000.

Dedman, B., "The Color of Money," Atlanta Constitution, May 1-4, 1988.

Dietrich, Jason, "The Effects of Choice-Based Sampling and Small-sample Bias on Past Fair Lending Exams, Economic and Policy Analysis Working Paper 2001-2. Washington, DC: Office of the Comptroller of the Currency, June 2001.

Dubovsky, Jean Eberhart, "Fair Housing: A Legislative History and a Perspective," Washburn Law Journal 8, 1969, 149-58.

Dymski, Gary A., "The Theory of Credit-Market Redlining and Discrimination: An Exploration," Review of Black Political Economy 23(3), Winter 1995, Pp. 37-74.

Dymski, Gary A., "Why Does Race Matter in Housing and Credit Markets?" in Race, Markets, and Social Outcomes, edited by Patrick L. Mason and Rhonda Williams. Boston: Kluwer Academic Press, 1997.

Dymski, Gary A., The Bank Merger Wave: The Economic Causes and Social Consequences of Financial Consolidation. Armonk, NY: M.E. Sharpe, 1999.

Dymski, Gary A., "Racial and Gender Disadvantage in the Credit Market: Social Injustice and Outcome Equality," in Robert Pollin, ed., Capitalism, Socialism And Radical Political Economy: Essays In Honor Of Howard J. Sherman, Cheltenham, UK and Northamption, MA: Edward Elgar, 2000. Pp. 227-46.

Dymski, Gary A., "Is Discrimination Disappearing? Racial Differentials in Access to Credit, 1992-1998," International Journal of Social Economics. 2001.

Dymski, Gary A., and Lisa Mohanty. "Credit and Banking Structure: Asian and African American Experience in Los Angeles," American Economic Review Papers and 
Proceedings. May 1999.

Dymski, Gary A., and John M. Veitch, "Taking It to the Bank: Credit, Race, and Income in Los Angeles." In Residential Segregation: The American Legacy. Edited by Robert D. Bullard, Charles Lee, and J. Eugene Grigsby, III. Los Angeles: Center for Afro-American Studies, 1994. Pp. 150-179.

Dymski, Gary A., and John M. Veitch, "Financial Transformation and the Metropolis: Booms, Busts, and Banking in Los Angeles," with John Veitch, Environment and Planning A. 1996.

Edelstein, Dana Lenore Gilbert, Women and Credit Discrimination. Ph.D. Dissertation, University of California, Davis, 1977.

Eggert, Kurt, "Limiting Abuse and Opportunism by Mortgage Services," Housing Policy Debate 15(3), 2004, Pp. 753-84.

Elmelech, Yuval, and Hsien-Hen Lu, "Race, Ethnicity, and the Gender-Poverty Gap," Social Science Research 33(1), March 2004, Pp. 158-82.

Engel, Kathleen C., and Patricia A. McCoy, "A Tale of Three Markets: The Law and Economics of Predatory Lending," Texas Law Review 80:6, 2002, 1255-1382.

Ferguson, Michael F., and Stephen R. Peters, "What Constitutes Evidence of Discrimination in Lending?” Journal of Finance, 50(2), June 1995. Pp. 739-48.

Figlio, David N., and Joseph W. Genshlea, "Bank Consolidations and Minority Neighborhoods," Journal of Urban Economics 45, 1999, Pp. 474-489.

Fishbein, Allen J., "The Ongoing Experiment with 'Regulation from Below': Expanded Reporting Requirements for HMDA and CRA," Housing Policy Debate 3(2), 1992. Pp. 601-636.

Freeman, Alan, "Legitimating racial discrimination through antidiscrimination law: a critical review of Supreme Court doctrine,” Minnesota Law Review, 62, 1978.

Fukuyama, Hirofumi, Ramon Guerra, and William L. Weber, "Efficiency and Ownership:

Evidence from Japanese Credit Cooperatives," Journal of Economics and Business 1999; 51, Pp. 473-487.

Galster, George C., "Research on Discrimination in Housing and Mortgage Markets: Assessment and Future Directions," Housing Policy Debate 3(2), 1992. Pp. 637-683.

Galster, George C., "The Facts of Lending Discrimination Cannot Be Argued Away by Examining Default Rates," Housing Policy Debate, 4(1), 1993. Pp. 141-6.

Galster, George C., and Ronald B. Mincy, "Understanding the Changing Fortunes of Metropolitan Neighborhoods: 1980 to 1990," Housing Policy Debate 4(3), 1993. Pp. 303-352. 
Glennon, Dennis and Mitchell Stengel, “An Evaluation of the Federal Reserve Bank of Boston's Study of Racial Discrimination in Mortgage Lending," Economic and Policy Analysis Working Paper 94-2. Washington, DC: Comptroller of the Currency, April 1994.

Goering, J.M., editor, "Race and Default in Mortgage Markets: A Colloquy," Cityscape: A Journal of Policy Development and Research 2, 1996.

Grown, Caren, and Timothy Bates, "Commercial Bank Lending Practices and the Development of Black Owned Construction Companies,” Journal of Urban Affairs 14(1), 1992, Pp. 25-41.

Guttentag, Jack M. and Susan L. Wachter, "Redlining and Public Policy," Monograph Series on Finance and Economics. No. 1. New York: Solomon Brothers Center for the Study of Financial Institutions, 1980.

Han, Song, "On the Economics of Discrimination in Credit Markets," Working Paper 200202, Division of Research and Statistics, Federal Reserve Board. Washington DC: October 2001.

Han, Song, "Discrimination in Lending: Theory and Evidence," Journal of Real Estate Finance and Economics 29(1), 2004, Pp. 5-46.

Hawley, C.A., and E. T. Fujii, "Discouraged Applicants for Consumer Credit," Economics Letters 33, 1990, Pp. 83-86.

Heckman, James, "The Common Structure of Statistical Models of Truncation, Sample Selection, and Limited Dependent Variables and a Sample Estimator for Such Models," Annals of Economic and Social Measurement 5, 1976, Pp. 475-92.

Heckman, James. J., "Sample Bias as a Specification Error," Econometrica 47, January, 1979, Pp. 153-61.

Henriques, Diana B., and Lowell Bergman, "Profiting From Fine Print With Wall Street's Help," Wall Street Journal, March 15, 2000.

Holmes, Andrew, and Paul Horvitz, "Mortgage Redlining: Race, Risk, and Demand," Journal of Finance, 49(1), March 1994, Pp. 81-99.

Hunter, William C., and Mary Beth Walker, "The Cultural Affinity Hypothesis and Mortgage Lending Decisions," Working Papers Series: Issues in Financial Regulation, Research Department, Federal Reserve Bank of Chicago, July 1995.

Hutchinson, Peter M., James R. Ostas, and J. David Reed, "A survey and comparison of redlining influences in urban mortgage lending markets," Journal of the American Real Estate and Urban Economics Association, Winter 1977.

Immergluck, Daniel, "Intraurban Patterns of Small Business Lending: Findings From the New Community Reinvestment Act Data," in Business Access to Capital and Credit. Chicago: Federal Reserve Bank of Chicago, 1999, Pp. 123-138. 
Immergluck, Daniel, “A Comment on 'Credit Risk and Mortgage Lending: Who Uses Subprime and Why? By Anthony Pennington Cross, Anthony Yezer, and Joseph Nichols'," Woodstock Institute. Chicago: Woodstock Institute, November 2000.

Kain, John F., “The Spatial Mismatch Hypothesis: Three Decades Later," Housing Policy Debate 3(2), 1992. Pp. 333-70.

Kasarda, John D., "Inner-City Concentrated Poverty and Neighborhood Distress: 1970 to 1990," Housing Policy Debate 4(3), 1993. Pp. 253-302.

Kelly, Austin, "Racial and Ethnic Disparities in Mortgage Prepayment," Journal of Housing Economics 4, 1995, Pp. 350-72.

Kim, Sunwoong, and Gregory D. Squires, "Lender characteristics and racial disparities in mortgage lending," Journal of Housing Research 6(1), 1995.

Lacker, Jeffrey, "Neighborhoods and Banking," Federal Reserve Bank of Richmond Economic Quarterly, 81(2), Spring 1995. Pp. 13-38.

LaCour-Little, Michael, and Richard K. Green, "Are Minorities or Minority Neighborhoods More Likely to Get Low Appraisals?" Journal of Real Estate Finance and Economics 16(3), 1998, Pp. 301-15.

LaCour-Little, Michael, "Discrimination in Mortgage Lending: A Critical Review of the Literature," Journal of Real Estate Literature 7, 1999, Pp. 15-49.

Ladd, Helen F., "Evidence on discrimination in mortgage lending." Journal of Economic Perspectives, 12(2), 1998, Pp. 41-62.

Lang, William W., and Leonard I. Nakamura, "A Model of Redlining," Journal of Urban Economics 33, 1993. Pp. 223-234.

Lax, Howard, Michael Manti, Paul Raca, and Peter Zorn, "Subprime Lending: An Investigation of Economic Efficiency," Housing Policy Debate 15:3, 2004, Pp. 533-71.

Lee, C.H., and E.H. Warren, "Rationing by Seller's Preference and Racial Price Discrimination," Economic Inquiry, 14, 1977. Pp. 36-44.

Leigh, Wilhelmina A., "Civil Rights Legislation and the Housing Status of Black Americans: An Overview," in The Housing Status of Black Americans, edited by Wilhelmina A. Leigh and James B. Stewart. New Brunswick, NJ: Transaction Publishers, 1992. Pp. 5-28.

Leitner, Yaron, "Fragile Financial Networks - A Preliminary Analysis," Working Paper 02-9. Philadelphia: Federal Reserve Bank of Philadelphia, June 2002.

Maddala, G.S., and Robert P. Trost, "On measuring discrimination in loan markets," Housing Finance Review, 1(3), 1982. Pp. 245-266. 
Martin, Robert E., and R. Carter Hill, “Loan Performance and Race,” Economic Inquiry 38(1), January 2000, Pp. 136-50.

Marsden, Madeline, "Board issues fair lending policy statement," Financial Update, Federal Reserve Bank of Atlanta, 7(1-2), January-June 1994. Pp. 1-3.

Mason, Patrick L., "The Divide-and-Conquer and Employer/Employee Models of Discrimination: Neoclassical Competition as a Familial Effect," Review of Black Political Economy, 20(4), Spring 1992, 73-89.

Massey, Douglas S., and Nancy A. Denton, American Apartheid: Segregation and the Making of the Underclass. Cambridge: Harvard University Press, 1993.

Masson, R. "Costs of Search and Racial Price Discrimination," Economic Inquiry, 1973. Pp. $167-86$.

Mohanty, Lisa, "Access to Credit: A Study of Minority Women in California," paper presented at the Western Social Science Association meetings, Reno. Mimeo, University of California, Riverside, June 2001.

Mollenkamp, Carrick, "Conceding Failure, First Union Plans to Close Money Store Unit," Wall Street Journal, June 26, 2000.

Munnell, Alicia H., Lynn E. Browne, James McEneaney, and Geoffrey Tootell, Mortgage Lending in Boston: Interpreting HMDA Data. Working Paper No. 92-7. Boston: Federal Reserve Bank of Boston, 1992.

Myers, Samuel L., and T. Chan, "Racial Discrimination in Housing Markets - Accounting for Credit Risk," Social Science Quarterly 76(3), September 1995, Pp. 543-61.

Nesiba, Reynold F., Deregulation and Discrimination: An Evaluation of the Impact of Bank Mergers on Residential Mortgage Lending Patterns in St. Joseph County Indiana 198593. Ph.D. dissertation, Department of Economics, University of Notre Dame, 1995.

Oliver, Melvin L., and Thomas M. Shapiro, Black Wealth / White Wealth: A New Perspective on Racial Inequality. New York: Routledge, 1995.

Olney, Martha, "When Your Word Is Not Enough: Race, Collateral, and Household Credit," Journal of Economic History 58(2), June 1998, Pp. 408-31.

Ondrich, Jan, Stephen L. Ross, and John Yinger, "How Common is Housing Discrimination? Improving on Traditional Measures," Journal of Urban Economics 47, 2000, Pp. 470-500.

Ondrich, Jan, Alex Stricker, and John Yinger, "Do Real Estate Brokers Choose to Discriminate? Evidence from the 1989 Housing Discrimination Study," Southern Economic Journal 64(4), April 1998, Pp. 880-901.

Oppel, Jr., Richard A., "U.S. Suit Cites Citigroup Unit on Loan Deceit," New York Times, March 
7, 2001.

Oppel, Jr., Richard A., and Patrick McGeehan, "Citigroup Announces Changes to Guard Against Abusive Loan Practices” New York Times, November 8, 2000.

Page, Marianne, "Racial and Ethnic Discrimination in Urban Housing Markets: Evidence from a Recent Audit Study," Journal of Urban Economics 38, 1995, Pp. 183-206.

Pennington-Cross, Anthony, Anthony Yezer, and Joseph Nichols, Credit Risk and Mortgage Lending: Who Uses Subprime and Why?, Working Paper No. 00-03. Washington, DC: Research Institute for Housing America, 2000.

Perle, Eugene D., Kathryn Lynch, and Jeffrey Horner, "Model Specification and Local Mortgage Market Behavior," Journal of Housing Research 4(2), 1993. Pp. 225-244.

Perlmann, Joel, “The Place of Cultural Explanations and Historical Specificity in Discussions of Modes of Incorporation and Segmented Assimilation," Working Paper No. 240. Annandale-on-Hudson, N.Y.: Jerome Levy Economics Institute of Bard College, July 1998.

Pollard, Jane, "Financial Exclusion in Los Angeles," Environment and Planning A. 1995.

Quercia, Roberto G., and Michael A. Stegman, "Residential mortgage default: a review of the literature," Journal of Housing Research, 3(2), 1992.

Rachlis, Mitchell B., and Anthony M.J. Yezer, "Serious flaws in statistical tests for discrimination in mortgage markets," Journal of Housing Research 4(2), 1993. Pp. 315336.

Read, Lauren, The Financing of Small Business: A Comparative Study of Male and Female Business Owners. London: Routledge, 1998.

Reibel, Michael. Fair Lending and Neighborhood Disinvestment in Los Angeles. Ph.D. Dissertation, Geography, University of California, Los Angeles, 1997.

Reibel, Michael, "Geographic Variation in Mortgage Discrimination: Evidence from Los Angeles," Urban Geography 21(1), January-February 2000, Pp. 45-60

Roemer, John, Equality of Opportunity. Cambridge: Harvard University Press, 1998.

Ross, Stephen I., "Mortgage Lending, Sample Selection, and Default," Real Estate Economics 28(4), 2000, Pp. 581-621.

Ross, Stephen L., and John Yinger, "Does Discrimination in Mortgage Lending Exist? The Boston Fed Study and Its Critics," Chapter 3 in Austin Turner and Skidmore (1999a). Pp. 45-83. (1999a)

Ross, Stephen L., and John Yinger, "Other Evidence of Discrimination: Recent Studies of 
Redlining and of Discrimination in Loan Approval and Loan Terms," Chapter 4 in Austin Turner and Skidmore (1999a). Pp. 85-106. (1999b)

Ross, Stephen L., and John Yinger, "The Default Approach to Studying Mortgage

Discrimination: A Rebuttal," Chapter 5 in Austin Turner and Skidmore (1999a). Pp. 10727. (1999c)

Sanders, Cynthia K. and Edward Scanlon, "Mortgage Lending and Gender." Affilia, 15 (1), 2000, Pp. 9-30.

Sapsford, Jathon, Paul Beckett, and John Hechinger, "Citigroup, J.P. Morgan Take Earnings Hits from Bad Loans, Lower Banking Revenue,” Wall Street Journal, October 18, 2001.

Scalera, Domenico, and Alberto Zazzaro, "Group Reputation and Persistent (or Permanent) Discrimination in Credit Markets," Journal of Multinational Financial Management 11(4-5), December 2001, Pp. 483-96.

Schafer, Robert, Mortgage lending decisions, criteria and constraints. Cambridge: Joint Center for Urban Studies, MIT and Harvard, December 1978.

Schafer, Robert and Helen F. Ladd, Equal Credit Opportunity: Accessibility to Mortgage Funds by Women and by Minorities: Final Technical Report. U.S. Department of Housing and Urban Development, Office of Policy Development and Research. Washington, DC: USGPO, 1980.

Schelling, Thomas, "Dynamic Models of Segregation," Journal of Mathematical Sociology 1, 1971. Pp. 143-86.

Schill, Michael H., and Susan M. Wachter, "A Tale of Two Cities: Racial and Ethnic Geographic Disparities in Home Mortgage Lending in Boston and Philadelphia," Journal of Housing Research 4(2), 1993. Pp. 245-276.

Schmitt, Brian T., "From Redlining to Creditlining: The Ways of White Folks," mimeo, Department of Planning and Public Policy, Rutgers University, New Brunswick, NJ, May 2000.

Schwemmer, Robert G., "Introduction to Mortgage Lending Discrimination Law," The John Marshall Law Review 28, Winter 1995, Pp. 317-32.

Shlay, Anne, "Financing Community: Methods for Assessing Residential Credit Disparities, Market Barriers, and Institutional Reinvestment Performance in the Metropolis," Journal of Urban Affairs 11(3), 1989. Pp. 201-23.

Simmons, Colin, and Salinder Supri, "Failing Financial and Training Institutions: The Marginalization of Rural Household Enterprises in the Indian Punjab," Journal of Economic Issues 33(4), December 1999, Pp. 953-74.

Smith, Shanna, "Women and Housing Discrimination," McAuley Institute, September 2000. 
Sowell, Thomas. Ethnic America: A History. New York: Basic Books, 1981.

Squires, Gregory, "Community reinvestment: an emerging social movement," in Gregory Squires, editor, From redlining to reinvestment. Philadelphia: Temple University Press, 1992. Pp. 1-37.

Squires, Gregory D., and Sally O'Connor, “Access to Capital: Milwaukee's Small Business Lending Gaps," in Business Access to Capital and Credit. Chicago: Federal Reserve Bank of Chicago, 1999, Pp. 85-122.

Staten, Michael E., and Anthony M. Yezer, "Introduction to the Special Issue," "Special Issue: 'Subprime Lending: Empirical Studies'," Journal of Real Estate Finance and Economics 29:4, 2004, Pp. 359-63.

Stiglitz, Joseph E., and Andrew Weiss, "Credit Rationing in Markets with Imperfect Information," in New Keynesian Economics, Vol. II, edited by Gregory Mankiw and David Romer, pp. 247-276. Cambridge: MIT Press, 1991.

Stone, Michael. One Third of the Nation. Washington, DC: Economic Policy Institute, 1991.

Stuart, Guy, Discriminating Risk: The U.S. Mortgage Lending Industry in the Twentieth Century. Ithaca, N.Y.: Cornell University Press, 2003.

Swire, Peter P., "The Persistent Problem of Lending Discrimination: A Law and Economics Analysis," Texas Law Review 73, March 1995, 787-869.

Struyk, Raymond J., and Margery A. Turner, "Exploring the Effects of Racial Preferences on Urban Housing Markets," Journal of Urban Economics 19, 1986. Pp. 131-47.

Tootell, Geoffrey, "Redlining in Boston: Do Mortgage Lenders Discriminate Against Neighborhoods?" Quarterly Journal of Economics, 111(4), November 1996, Pp. 1049-79.

U.S. Department of Housing and Urban Development (HUD), Unequal Burden in Los Angeles: Income and Racial Disparities in Subprime Lending. Washington, DC: U.S. Department of Housing and Urban Development, April 2000.

United States House of Representatives. 1974. Credit Discrimination. Hearings before the Subcommittee on Consumer Affairs of the Committee on Banking and Currency, House of Representatives, Ninety-third Congress, second session. Washington, DC: USGPO.

Weink, Ron, "Discrimination in Urban Credit Markets: What We Don't Know and Why We Don’t Know It," Housing Policy Debate, 3(2), 1992. Pp. 217-240.

White, Alan M., "Risk-Based Mortgage Pricing: Present and Future Research," Housing Policy Debate 15:3, 2004, Pp. 503-31.

Wiggins, Mary Jo, "Race, Class, and Suburbia: The Modern Black Suburb as a "Race-Making Situation'," University of Michigan Journal of Law Reform 35, Summer 2002, 749-808. 
Williams, Richard. "The Effect of GSEs, CRA, and Institutional Characteristics on Home Mortgage Lending to Underserved Markets." HUD Final Report, December 1999.

Wilson, William Julius, The Truly Disadvantaged: The Inner City, the Underclass, and Public Policy. Chicago: University of Chicago Press, 1987.

Wolff, Edward N., "Racial Wealth Disparities: Is the Gap Closing?" Public Policy Brief No. 66. Annandale-on-Hudson, N.Y.: Jerome Levy Economics Institute of Bard College, 2001.

Wyly, Elvin, Mona Atia, and Daniel J. Hammel, "Has Mortgage Capital Found an Inner-City Spatial Fix?" Housing Policy Debate 15:3, 2004, Pp. 623-85.

Yezer, Anthony M.J., "Studies of CRA Lending on Small Business Lending," in Business Access to Capital and Credit. Chicago: Federal Reserve Bank of Chicago, 1999, Pp. 139-45.

Yinger, John, “A Model of Discrimination by Landlords," Working Paper 259-75, Institute for Research on Poverty, University of Wisconsin - Madison, February 1975.

Yinger, John, "Cash in Your Face: The Cost of Racial and Ethnic Discrimination in Housing," Journal of Urban Economics 42, 1997, Pp. 339-65.

Zenou, Yves, and Nicolas Boccard, "Racial Discrimination and Redlining in Cities," Journal of Urban Economics 48, 2000, 260-85. 